[Deutsche Entomologische Zeitschrift XXIX. 1885. Heft I.]

\title{
Beitrag zur Staphylinenfauna West-Afrika's
}

von

Dr. E. Eppelsheim in Grünstadt.

So sorgfältig die Fauna der nordwest-afrikanischen Inselgruppen 1) erforscht ist, welche hinsichtlich der Gesammtkäfer, also auch der Staphylinen, in den Arbeiten von Lucas ${ }^{2}$ ) und namentlich von Wollaston ${ }^{3}$ ) eine eingehende Beschreibung gefunden hat, so dürftig ist es mit unsern Kenntnissen über die Kurzflügler des westafrikanischen Festlandes bestellt. Zwar haben die Sammelergebnisse der entomologischen Explorationen in den Senegal-Ländern und in Guinea in vielen Käferfamilien ein Material zu Tage gefördert, reichlich genug, um einen einigermafsen genügenden Einblick zu gestatten sowohl in die specifischen Eigenthümlichkeiten ihrer Fauna als auch in die verwandtschaftlichen Beziehungen derselben zu anderen näheren oder entfernteren Faunengebieten des übrigen Afrika; aber speziell die Familie der Staphylinen war in diesen Sammlungen so stiefmütterlich bedacht, dafs sie geraume Zeit hindurch nur durch einige wenige Arten vertreten war. Diese sind: Aleochara loricata Er., Xantholinus (Eulissus) ater Lap., Platyprosopus senegalensis Dej., Cryptobium senegalense Lap., Paederus aestuans und sabaeus Er. und senegalensis Lap. Erichson bat denselben in seiner, namentlich für die geographische Verbreitung der Käfer so werthvollen Schrift über die Insekten von Angola ${ }^{4}$ ) 6 neue Arten hinzugefügt, Myrmedonia satelles und suturalis, Philonthus hospes, Cryptobium tricolor, Paederus angolensis und Oedichirus terminatus, welche durch Quedenfeldt ${ }^{5}$ ) um weitere

1) Von den übrigen Inseln West-Afrika's ist nur St. Helena in entomologischer Beziehung bekannt geworden durch: Wollaston, Col. Sanct. Helenae 1878.

2) In Webb et Berthelot, hist. nat. des îles Canar.

${ }^{3}$ ) Wollaston, Insect. Mader. 1854 und Cat. Col. Mader. 1857. Cat. Canar. Col. 1864.

Col. Atlantid. 1865.

Col. Hesperid. 1867.

4) Wiegmann, Arch. f. Naturgesch. IX, I, p. $199 \mathrm{ff}$.

$\left.{ }^{5}\right)$ Berl. Ent. Zeitschr. 1881, p. 293 und 294. 
2 Arten, Xantholinus coeruleipeunis und Dolicaon angolensis vermehrt wurden. Fernerhin hat Kraatz aus Guinea die neue Gattung Pygostenus ${ }^{1}$ ) mit einer Art und aus Senegambien die Gattungen Glyphestes ${ }^{2}$ ) mit 2 Arten und Homorocerus ${ }^{3}$ ) mit einer Art aufgestellt, welche letztere von Solsky ${ }^{4}$ ) durch eine 2te Art von der an der senegambischen Küste dem Cap Verd gegenüberliegenden Insel Gorée bereichert wurde. Endlich hat Harold ${ }^{5}$ ) einen Xantholinus nasutus vom Congo beschrieben. Das ist Alles, was bis jetzt über die Staphylinenfauna West-Afrika's bekannt geworden war, oder vielleicht richtiger gesagt - was wir bislang über dieselbe aus entomologischen Schriften erfahren baben.

Um so dankbarer erschien mir unter diesen Verhältnissen die Aufgabe, die Resultate einer Staphylinensendung zu veröffentlichen, welche ich der hochherzigen Liberalität meines verehrten Freundes Hans Simon in Stuttgart verdanke. Sämmtliche Thiere sind bei Adda an der Goldküste von Hrn. Missionär Kopp gesammelt, welchem an diesem Orte -der aufrichtigste Dank für seine die Wissenschaft fördernden Bemühungen ausgesprochen sein möge. Das Sammeln selbst geschah in denkbar primitivster Weise, lälst aber einen Einblick in die ungeheueren Insektenschätze des Landes thun, welche bei einer verständnifsvollen und kunstgerechten Sammelmethode gehoben werden könnten. Fast alles Gesammelte nämlich wurde an einigen schwülen feuchten Abenden in dem beleuchteten Zimmer des Hrn. Kopp dadurch erbeutet, dafs tausende von den Thierchen, welche, durch den Lichtreiz angezogen, durch die geöffneten Fenster ins Zimmer drangen und sich auf Tischen, an den Wänden u.s. w. niederliefsen, nun mit einem feinen Besen auf eine kleine Blechschaufel gekehrt und darauf in Spiritus geworfen wurden. Es mag auffallend erscheinen, dafs unter den auf diese Weise erbeuteten Thieren sich auch 8 Myrmedonia-Arten, jedenfalls echte Termitengäste, befanden, allein diese Erscheinung steht mit der Thatsache in vollkommenem Einklang, dafs ich hier in Grünstadt an den von der Abendsonne beleuchteten und erwärmten Fenstern einer Gartenkegelbahn zu wiederholten Malen mehrere Myrmedonien fing, die ich bisher nur als ausschliefsliche Bewohner der Ameisennester gekannt hatte, wie humeralis, cognata, laticollis. Wenige

1) Berl. Ent. Zeitschr. 1858, p. 361 .

2) ibid. p. 364 .

$\left.{ }^{3}\right)$ ibid. p. 363 .

4) ibid. 1864, p. 375 .

$\left.{ }^{5}\right)$ Col. Heft. XVI, p. 27. 
Stücke nur wurden an andern Orten bei Adda hier und da gelegentlich von Hrn. Kopp und von Negerknaben gefunden und eingethan. Die Zahl der gesammelten Arten beträgt 52 und zwar 10 Aleocharinen, 1 Tachyporinen, 4 Staphylininen, 30 Paederiden, 1 Steniden und 6 Oxytelinen. Alle gehören bereits bekannten Gattungen an, ein Umstand, der nicht befremden kann, wenn man berücksichtigt, wie einförmig ganze Faunen auf dem afrikanischen Festlande sind. Der weitaus grölste Theil ist neu und der Goldküste eigen, wenigstens bis jetzt nicht anderswo in Afrika aufgefunden, einen kleineren Theil hat dieselbe mit anderen Gebietstheilen Afrika's gemein und zwar:

a) Lathrobium caffer und Paederus capensis mit den Capländern.

b) Oedichirus terminatus mit Angola.

c) Edaphus africanus und Pinophilus reticulatus mit Nubien und Abyssinien und mit diesen Ländern und Senegambien zugleich Paederus sabaeus Er. (aestuans Boh.).

d) Mit dem grünen Vorgebirge Scopaeus laetus und Bledius gemellus und mit den Cap Verdischen Inseln Tanygnathus varicornis. Namentlich am grünen Vorgebirge dürften jedoch noch manche Arten aufgefunden werden, die bis jetzt blofs von den Cap Verdischen Inseln bekannt sind und sich höchst wahrscheinlich noch weiter die Küste herab verbreiten.

e) Mit der Nordküste Afrika's hat die Goldküste keine Art gemein, möge nun der Atlas oder die Sahara dahinter die Faunen scheiden, denn der an den beiderseitigen Küsten des Mittelmeeres häufiger und auch bei Adda zahlreich gesammelte Philonthus quisquiliarius ist ein Cosmopolit, der aufser Europa und vielen Gebieten Afrika's auch in Asien und Nordamerika gefunden wurde.

Aus all diesem erhellt, dafs die Fauna der Goldküste sowohl an derjenigen der nördlich wie südlich von derselben gelegenen Gebietstheile, wie auch an der Fauna der entgegengesetzten Küste von Nubien participirt, dafs also, wie schon Erichson hervorhebt, weder in der Richtung der geographischen Länge noch der Breite strenge Faunenscheiden existiren und demnach Verbältnisse gegeben sein müssen, welche dem Vordringen und der Verbreitung der Thiere weder von Ost nach West mitten durch den Erdtheil hindurch, noch von Süden nach Norden und umgekehrt wesentliche Hemmnisse in den Weg legen. Doch wird erst reicheres und namentlich aus den $\mathrm{Z}$ wischenpunkten der einigermafsen erforschten Gegenden stammendes Material zuverlässigeren Aufschlufs über die 
Selbstständigkeit oder Zusammengehörigkeit der einzelnen Faunen Afrika's geben können.

Möge an der Lösung dieser Aufgabe Hr. Kopp, der gegenwärtig in Cannstadt weilt, auch fernerhin mitarbeiten und möge er uns, nach Adda zurückgekehrt, noch weiter mit seinen Sendungen unterstützen! Mögen vor Allem aber die von allen mafsgebenden Kreisen enthusiastisch begrüfsten neuen Colonialbestrebungen des deutschen Reiches in West-Afrika, wie sie Licht werfen werden auf die übrigen Erzeugnisse der erworbenen Gebirgstheile, so auch mit der Zeit der entomologischen Forschung zu Gute kommen und unsere noch so mangelhaften Kenntnisse von der Fauna des Westens des gewaltigen Erdtheiles allmählig mehr und mehr bereichern!

Nach diesen einleitenden Bemerkungen gehe ich zur Aufzählung der gesammelten Arten über.

\section{Myrmedonia aculeata n. sp.}

Rufa, subnitida, capite, elytris abdomineque posterius nigris, antennarum basi pedibusque testaceis; antennis elongatis, gracilibus, capite transverso thoracis fere latitudine, hoc subtransverso, posterius distincte angustato, lateribus basique alte marginato, ante scutellum transversim impresso; elytris thorace parum longioribus creberrime fortius scabrose punctatis; abdomine laevi, nitido, segmento $6^{0}$ in utroque sexu lateribus plicato-carinato. - Long. 3 lin.

Mas: Abdominis segmento superiore secundo apice paullo producto spinis tribus, medio breviore, terminato, tertio postice medio tuberculis tribus elongatis, acutis, subdentiformibus, parallelis, approximatis munito, sexto medio apicem versus carinato-elevato.

Von gestreckter, ziemlich gleichbreiter Gestalt, oben wenig gewölbt, der Vorderkörper fein anliegend grau behaart und im Grunde äufserst fein lederartig gewirkt, daher nur mit gedämpftem Glanze seiner Oberfläche, der Hinterleib glatt und glänzend. Die ganze Unterseite ist hell rothbraun, nur das 5te und 6te Segment schwarz mit rothem Hintersaume, das 7 te wieder fast ganz rothbraun; oben sind der Kopf, die Flügeldecken und die hintere Hälfte des Abdomen schwarz, das Halsschild, die Vorderhälfte des Hinterleibes und die Fühler roth, deren Basis und die Beine gelbröthlich; auf dem Hinterleibe geht jedoch die helle Farbe - zumeist in der Mitte des 5ten Segmentes - nur allmählig und verschwommen in die schwarze über. Der Kopf ist breit, fast so breit als das Halsschild, an den Seiten fast gerade, nach rückwärts kaum verengt; 
die Augen sind grofs aber wenig vorstehend und nehmen den weitaus grölsten Theil der Seiten des Kopfes ein; oben ist der Kopf sparsam, nicbt fein aber oberfächlich punktirt und fein und sparsam behaart, nach vorn zu fast ganz glatt, der Scheitel ist der Quere nach gewölbt, die Stirn ziemlich flach, beim or breit und seicht eingedrückt. Der Mund und die schlanken langen Taster sind rothgelb, die Mandibeln an der Spitze schwarz. Die schlanken fadenförmigen Fühler reichen zurückgelegt bis zum Hinterrande der Flügeldecken, ihr 3tes Glied ist um die Hälfte länger als das 2te, die folgenden an Länge wie an Breite kaum verschieden, alle um mehr als die Hälfte länger als breit, das Endglied anderthalb mal so lang als das 10te. Das Halsschild ist vorn kaum um die Hälfte breiter als lang, nach rückwärts verengt, vorn fast gerade abgeschnitten, an den Seiten und hinten sanft gerundet mit stumpfabgerundeten Vorder- und Hinterecken, längs der Seiten und der Basis ziemlich tief eingedrückt, so dafs die scharf erhabenen Seitenränder und der Hinterrand wie aufgestülpt erscheinen, oben nur mäfsig gewölbt, mit feinen punktförmigen Körnchen etwas dichter als der Kopf besetzt, hinten vor dem Schildchen mit einer breiten kurzen Quergrube, welche zuweilen, besonders beim $\sigma^{\top}$, in eine schwache Längsrinne ausläuft. Die Flügeldecken sind an der Basis um ein Drittel breiter als der Hinterrand des Halsschildes, nach hinten etwas verbreitert, mit wenig vorstehenden Schultern und seichter kaum merklicher Ausbuchtung des Hinterrandes vor den Hinterecken, oben äufserst dicht, kräftiger als das Halsschild, reibeisenartig punktirt. Der Hinterleib ist etwas schmäler als die Flügeldecken, gegen die Mitte hin etwas erweitert, nach der Spitze zu wieder sanft verengt, auf dem breiten stark erhabenen Seitenrande punktirt, sonst glatt, glänzend, unbehaart, auf dem vorletzten Segmente in beiden Geschlechtern beiderseits längs des Seitenrandes mit einer kielartig erhabenen Längsfalte. Die Beine mit den Tarsen sind lang und schlank, rothgelb.

Beim $\sigma^{\pi}$ ist der 2te obere Hinterleibsring an der Spitze in 3 leicht aufwärts gerichtete Dorne ausgezogen, einen mittleren, schwächeren und kürzeren und 2 seitliche längere, zwischen denselben in breitem Bogen ausgerandet, aufserdem fein aber deutlich gekörnt-punktirt. Das 3te Segment hat in der Mitte drei parallel verlaufende oben scharf zugehende, zahnartige Längserhabenheiten, welche von der Mitte des Segmentes bis zum Hinterrand reichen, das vorletzte aufser den seitlichen Längsfalten in der Mitte einen scharf erhabenen Längskiel. 
Das Thier ist in der Färbung der abyssinischen $\boldsymbol{M}$. inclita Fauv. am nächsten stehend, aber von ganz anderer Sculptur. Es wurde in etwa 2 Dutzend Exemplaren erbeutet.

\section{Myrmedonia piciceps n. sp.}

Elongata, subparallela, parum convexa, nitida, rufo-testacea, capite solo nigro-piceo, thoracis fere latitudine; antennis gracilioribus apicem versus haud incrassatis; thorace transversim quadrato posterius subangustato basi transversim impresso; elytris hoc parum longioribus abdomineque supra segmentis 5 primis crebrius punctatis, $6^{0}$ laevigato, utrinque plicato-elevato. - Long. $2 \frac{1}{2}$ lin.

Mas: Abdominis segmento superiore $7^{0}$ parcius exasperatopunctato, apice subrotundato parceque subtiliter denticulato.

Eine wenig ausgezeichnete Art von gestreckter fast gleichbreiter Gestalt, oben wenig gewölbt, glänzend, fein und sparsam behaart, mit Ausnahme des pechschwarzen Kopfes einfarbig rothgelb. Dieser ist etwas schmäler als das Halsschild, quer, an den Seiten fast gerade, nach hinten nicht verengt, die Augen grofs aber flach, nicht hervortretend, mit dem Seitenrand in einer Linie gelegen, die Stirn wenig gewölbt, äufserst fein, ganz vereinzelt punktirt. Der Mund, die Taster und Fühler sind einfarbig, rothgelb, letztere länger als Kopf und Halsschild, nach der Spitze nicht verdickt, das 3te Glied wenig länger als das 2 te, das 4 te und 5 te etwas kürzer und breiter als dieses, die folgenden an Länge und Breite kaum verschieden, alle etwa so lang als breit und nach der Basis zu stark verengt, trichterförmig, das Endglied so breit als das 10te und etwas länger als die 2 vorletzten zusammen, vorn scharf zugespitzt. Das Halsschild ist querquadratisch, etwa um die Hälfte breiter als lang, nach hinten wenig verengt, an den Seiten fast gerade mit breit abgerundeten Vorder- und stumpf zugerundeten Hinterecken, oben in der Mitte mäfsig gewölbt, den Seiten entlang breit aber flach, schräg eingedrückt, vor dem Schildchen mit einer tiefen Quergrube, wenig dicht, ziemlich fein punktirt. Die Flügeldecken sind wenig breiter und etwas länger als das Halsschild, am Hinterrande vor den scharf vorstehenden Hinterecken breit und seicht ausgerandet, oben wenig gewölbt, ziemlich dicht, viel stärker und rauher als das Halsschild punktirt. Der Hinterleib ist etwas schmäler als die Flügeldecken, fast gleichbreit, breit gerandet, auf den fünf vorderen Segmenten mälsig dicht und fein punktirt, auf dem 6ten fast ganz glatt, längs des Seitenrandes mit einem kielartigen Fältchen geziert. Die Beine sind einfarbig rothgelb. - Beim $ð$ ? ist 
das 7te Segment oben rauh und körnig punktirt, an der Spitze leicht abgerundet und sparsam und schwach gezähnelt. - Es ist wahrscheinlich, dafs die seitlichen Längskiele des 6ten Segmentes den beiden Geschlechtern gemeinschaftlich sind.

Ein einziges $\sigma^{\Uparrow}$ ?

Ich kann das eben beschriebene Thier nur mit Zweifel als $\sigma^{\nearrow}$ beanspruchen, da das einzige mir vorliegende Stück nach Analogie der weiblichen Geschlechtsauszeichnung der folgenden Art ebensogut auch ein $q$ sein könnte. Zur Lösung dieser Frage wären eben weiter gesammelte Stücke nothwendig.

\section{Myrmedonia Koppi n. sp.}

Elongata, nitida, fusca, capite abdominisque cingulo postico nigris, thoracis margine laterali abdomineque rufescentibus, antennis elongatis fliformibus pedibusque testaceis; thorace transverso, lateribus rotundato, secundum marginem lateralem et ante scutellum impresso; elytris hoc parum longioribus crebre exasperato-punctatis; abdomine segmentis anterioribus parcius evidenter punctato, posterius fere laevigato, segmento $6^{0}$ in utroque sexu utrinque longitudinaliter plicato, $7^{0}$ subtilissime granulato, apice denticulato. - Long. $2 \frac{1}{2}$ lin.

Mas: Abdominis segmento $6^{0}$ apicem versus densius granulato granulisque pluribus majoribus arcuatim positis ornato.

In Form und Punktirung der vorhergebenden Art recht ähnlich, aber doch in vielen Punkten abweichend, bei gleicher Länge mit derselben breiter und anders gefärbt. Der Körper ist ziemlich gestreckt, oben wenig gewölbt, sparsam und fein anliegend behaart, glänzend, der Kopf und ein schmaler Hinterleibsgürtel, welcher das 5 te und die vordere Hälfte des 6ten Segments - aber nicht in scharfer Abgrenzung - einnimmt, schwarz, Halsschild und Flügeldecken kastanienbraun, ersteres mit breit hellerem Seitenrande, der Hinterleib vorn und an der Spitze rostroth, die Fühler und Beine hell gelbroth. Der Kopf ist wie bei der vorhergehenden Art gebildet, etwas schmäler als das Halsschild, oben an den Seiten fein und sparsam punktirt, in der Mitte fast ganz glatt. Auch die Form der Fühler ist ganz wie bei $M$. piciceps, nur sind dieselben noch länger und schlanker, fast bis zum Hinterrande der Flügeldecken reichend, die einzelnen Glieder, auch die vorletzten, entschieden länger als breit. Das Halsschild ist fast doppelt so breit als lang, an den Vorder- und Hinterecken stumpf zugerundet, an den Seiten leicht gebogen, nach hinten kaum mehr als nach vorn verengt, längs des Seitenrandes breit und tief schräg eingedrückt, 
vor dem Schildchen mit einem mäfsig tiefen Quergrübchen versehen, wie bei der vorigen Art punktirt und behaart. Auch die Flügeldecken sind ganz von derselben Länge und Form wie bei dieser, nur etwas rauher, schwach reibeisenartig punktirt. (Die Punkte von hinten eingestochen.) Der Hinterleib ist auf dem 2ten Segment ziemlich dicht und kräftig, leicht körnig, auf dem 3 ten etwas weniger bestimmt, auf dem 4 ten nur vorn und an den Seiten vereinzelt punktirt, auf den folgenden fast ganz glatt, auf dem 7 ten Segment dagegen wieder dicht und fein gekörnt und am Hinterrande gezähnelt, auf dem 6ten beiderseits wie bei den vorhergehenden Arten mit einem kielförmigen Längsfältchen geziert.

Beim $\sigma^{\tau}$ ist das 6te Segment auf der hintern Hälfte granulirt, in der Mitte der gekörnelten Stelle mit 6 in einen Halbkreis gestellten grölseren Körnchen geschmückt.

Von der vorigen Art durch andere Färbung, breitere Gestalt, namentlich breiteres Halsschild und schlankere Fühler unterschieden.

In einem Pärchen von Hrn. Kopp aufgefunden und ihm zu Ehren benannt.

\section{Myrmedonia piliventris n. $\mathrm{sp}$.}

Elongata, subfusiformis, nitida, picea, capite abdomineque nigricantibus, antennis pedibusque ferrugineis; capite brevi thorace fere latiore, oculis magnis prominulis, antennis validioribus elongatis; thorace subquadrato, secundum basin transversim, juxta margines posticos oblique impresso, his margineque basali calloso-reflexis; elytris postice thorace duplo fere latioribus et parum longioribus thoraceque sparsim asperato-punctatis; abdomine supra densius distincte punctato griseoque pubescente, segmentis singulis secundum apicem margineque laterali longe nigro-pilosis, segmento $6^{0}$ utrinque plicato-elevato. - Long. $2 \frac{1}{3}-2 \frac{3}{4}$ lin.

Eine höchst prägnante Art, in der Mitte erweitert, nach vorn und noch mehr nach hinten verschmälert, daher von annähernd spindelförmiger Gestalt, wenig gewölbt, die Flügeldecken und das Halsschild pechbraun, letzteres mit rothbraunen Rändern, der Kopf und der Hinterleib schwärzlich, der letztere mit breit rothbraunem Hinterrand der Segmente, die Fühler und Beine rostroth. Der Kopf ist breit und kurz, fast breiter als das Halsschild, an den Seiten und dem Hinterrande in gleichmäfsigem Bogen gerundet, hinten tief eingeschnürt und durch einen kurzen schmalen Hals dem Thorax eingefügt, oben der Quere nach gewölbt, vereinzelt und schwach punktirt, fein und sparsam behaart, der Scheitel mit einem 
schwachen Grübchen, die Augen grofs, vorstehend, die ganzen Seiten des Kopfes einnehmend. Die Fühler sind rostroth, an der Basis hell gelbroth, lang und kräftig, viel länger als Kopf und Halsschild, nach der Spitze zu nicht verdickt, alle Glieder länger als breit, nach der Basis schwach verengt, fast cylindrisch, das 3te Glied um die Hälfte länger als das 2te, das Endglied so lang als die 3 vorhergehenden zusammen, schräg zugespitzt. Das Halsschild ist fast quadratisch, kaum um ein Drittel breiter als lang, am Vorder- und Hinterrand leicht gerundet, mit breit abgerundeten Vorder- und fast rechtwinkligen Hinterecken, an den Seiten gerade, nach hinten nicht verengt, längs der Basis der Quere nach, neben den Hinterecken in schräger Richtung tief eingedrückt, so dafs die letzteren und der Hinterrand wie aufwärts gebogen und schwielig verdickt erscheinen, oben mit vereinzelten schräg eingestochenen ziemlich kräftigen Punkten und sparsamen grauen anliegenden Haaren besetzt. Die Flügeldecken sind an der Basis etwa um die Hälfte breiter als das Halsschild, von den Schultern an in leichtem Bogen nach hinten erweitert und hier wohl doppelt so breit als das Halsschild, wie dieses punktirt und behaart, am Hinterrande schräg nach innen abgeschnitten mit fast rechtwinkeligen Hinterecken. Der Hinterleib ist vorn nur wenig schmäler als der Hinterrand der Flügeldecken, bis zur Spitze des 3ten Segments noch bogenförmig erweitert, von da nach rückwärts allmählig verengt, oben dicht und deutlich punktirt und anliegend grau behaart, längs des Hinterrandes der einzelnen Segmente, an den Seiten und der Spitze mit langen schräg abstehenden schwarzen Haaren besetzt, auf dem 6ten und 7 ten Segmente fast glatt, auf dem 6ten neben dem Seitenrande mit einer kielförmigen Längsfalte. Unten ist der Hinterleib längs des Hinterrandes der einzelnen Segmente in doppelter Querreihe gleichfalls mit langen abstehenden Haaren besetzt. Die Beine sind rostroth.

Geschlechtsunterschiede sind bei den 3 mir vorliegenden Exemplaren nicht wahrzunehmen; bei denselben ist der Hinterrand des 7 ten oberen Ringes sanft gerundet.

\section{Myrmedonia angusticollis n. sp.}

Elongata, nitida, glabra, sublaevis, rufo-brunnea, capite abdomineque paullo obscurioribus, antennis elongatis fliformibus pedibusque rufo-testaceis; capite brevi transverso postice constricto oculis magnis prominulis; thorace elongato, lateribus antice rotundatoampliato, dein subito coarctato, ante scutellum profunde transversim impresso medioque subtiliter canaliculato; elytris thorace dimidio 
latioribus paulloque longioribus; abdomine apicem versus attenuato supra parce griseo-pubescente parceque longe nigro-piloso, subtus densius longiusque subaequaliter fulvo-griseo-piloso, segmentis $6^{0}$, $7^{0}$-que supra utrinque plicato-carinatis. - Long. $2 \frac{1}{2}$ lin.

Durch die, fast jeglicher Sculptur entbehrende, glatte Oberfäche besonders ausgezeichnet, ziemlich gestreckt, oben mäfsig gewölbt, glänzend, auf dem Vorderkörper mit einigen wenigen, kaum wahrnehmbaren, undeutlichen Pünktchen und kurzen Härchen besetzt, auf dem Hinterleib deutlicher und länger behaart. Die Farbe des Körpers ist ein glänzendes Rothbraun, die Flügeldecken und der Hinterleib wenigstens in der Mitte sind unmerrklich dunkler, der Kopf ist pechbraun. Letzterer ist wie bei der vorigen Art gebildet, kurz und breit, fast breiter als das Halsschild, hinten tief eingeschnürt, mit grofsen vorgequollenen Augen und kaum gewölbter, glänzend glatter Stirn. Die Fühler sind lang und schlank, viel länger als Kopf und Halsschild, nach der Spitze zu nicht verdickt, auch die vorletzten Glieder noch um die Hälfte länger als breit, das dritte Glied etwas länger als das 2te, das Endglied so lang als die zwei vorhergehenden zusammen. Das Halsschild ist länger als breit, an den Seiten vorn gerundet erweitert, dann plötzlich, vor der Mitte noch, eingeschnürt und von da zur Basis in gerader Linie verlaufend, am Vorderrand beiderseits schräg gerundet abgeschnitten, hinten in schwachem Bogen gerundet mit stumpfen Hinterecken, oben in der Mitte von einer tiefen Längslinie durchzogen, welche hinten vor dem Schildchen in eine breite und tiefe Quergrube ausläuft. Die Flügeldecken sind um die Hälfte breiter und nur wenig länger als das Halsschild, nach hinten sehr unbedeutend erweitert, am Hinterrand schräg abgeschnitten, mit stumpf abgerundeten Hinterecken. Der Hinterleib ist vorn fast so breit als die Flügeldecken, bis zum 3ten Segment noch etwas erweitert, von da bis zur Spitze dann allmählig verengt, an den Seiten hoch und breit gerandet, oben kaum punktirt, mit sparsamen anliegenden mäfsig langen graugelben und längs des Hinterrandes der einzelnen Segmente mit einzelnen längeren etwas abstehenden schwarzen Haaren besetzt, unten dichter und gleichmäfsig mit graugelben, in Querreihen stehenden Haaren überzogen, neben dem Seitenrande des 6 ten und 7 ten oberen Segmentes mit einer kielartig erbabenen Längsfalte geziert. Die Beine nebst den Tarsen sind lang und schlank.

Es liegen mir nur 3 Exemplare vor, an denen ich keinen Geschlechtsunterschied wahrzunehmen vermag. Bei allen ist das 
7te obere Segment nach der Spize zu verschmälert, an der Spitze selbst abgerundet.

\section{Myrmedonia costata n. sp.}

Elongato, deplanata, subopaca, fusca, capite abdomineque nigris, antennis pedibusque testaceis; capite transverso, basi utrinque pone oculos prominulos subdentato, supra impresso, 6 tuberculato; thorace subquadrato subrecte bi-, elytris transversis oblique tri-costatis, abdomine creberrime subtilissime strigoso-punctato griseoque pubescente, segmento sexto juxta marginem lateralem utrinque longitudinaliter plicatulo. - Long. $1 \frac{3}{4}$ lin.

Eine in ihrer Skulptur höchst eigenthümliche und in der Gattung einzig dastehende Art, ziemlich gestreckt, oben fast flach gedrückt, wenig glänzend, auf dem Vorderkörper glatt, unbehaart, auf dem Hinterleib äufserst fein und dicht anliegend grau behaart. Kopf und Hinterleib sind schwarz, letzterer mit rothbraunem Hinterrand der einzelnen Segmente, Halsschild und Flügeldecken bräunlich, letztere mit einem dunkleren Anflug um das Schildchen und in den Hinterecken, Fübler und Beine hell rothgelb. Der Kopf ist mit den grofsen vorgequollenen Augen so breit als das Halsschild; hinter denselben bilden der Hinterrand mit dem Seitenrande einen zahn- oder höckerartigen Vorsprung; oben ist er eingedrückt, glatt, unpunktirt, der eingedrückte Theil von 6 in regelmäfsigem Sechseck stehenden Tuberkeln begrenzt, von denen die hintersten im Hinterrande stehen, in der Mitte von einer feinen Längslinie durchzogen. Der Mund mit den Tastern und die Fühler sind einfarbig, hell gelbroth, die letzteren lang, über die Mitte der Flügeldecken hinausreichend, nach der Spitze zu verdickt, ihr erstes Glied kräftig und lang, stark verdickt, die 3 folgenden gestreckt, schlank, das 3te etwas länger als die beiden einschliefsenden gleichlangen; vom 4ten an nehmen die einzelnen Glieder allmählig an Länge aban Breite $\mathrm{zu}$, die ersten von ibnen sind länger als breit, die vorletzten schwach transversal, das Endglied gut doppelt so lang als die beiden vorhergehenden, eiförmig zugespitzt. Das Halsschild ist quadratisch, kaum etwas breiter als lang, nach hinten unmerklich verschmälert, an den scharfen Seiten fast gerade, an den Vorderecken breit abgerundet, oben abgeflacht, glatt, unpunktirt, in der Mitte der ganzen Länge nach von zwei fast geraden parallel verlaufenden, nach hinten zu schwach convergirenden Längsrippen durchzogen, zwischen denen in der Tiefe eine fein eingegrabene Längslinie veriäuft. Die Flügeldecken sind fast doppelt so breit und 
unmerklich länger als das Halsschild, an den Hinterecken abgerundet, oben von drei schrägen Längsrippen durchzogen, von denen die erste von der Innenseite des Schildchens zur Spitze der Naht, die 2te vor, die 3te hinter den Schultern zum Hinterrand verläuft, zwischen den Rippen äufserst fein, ziemlich dicht gekörnt. Der Hinterleib ist schmäler als die Flügeldecken, an den Seiten gebogen, bis zum Hinterrande des 3ten Segments erweitert, von da bis zur Spitze allmählig wieder verschmälert, am Seitenrande scharf aufwärts gebogen, oben äufserst dicht und fein, auf den beiden letzten Segmenten etwas weniger dicht längsstrichelich punktirt, in der Mitte des 2ten und 3ten Ringes der Länge nach schwach dachförmig erhaben und gegen die Seiten hin etwas eingedrückt, auf den folgenden der Quere nach eingedrückt, auf dem vorletzten neben dem Seitenrande mit einem erhabenen Längsfältchen geziert. Die Hinterbeine sind etwas verlängert, nebst den Tarsen dünn und schlank.

Es liegen mir nur 2 Stücke vor, welche $q$ zu sein scheinen.

\section{Myrmedonia marginata n. sp.}

Elongata, sublinearis, subconvexa, nitidula, anterius fortiter aspereque punctata, ferruginea, capite, elytris abdomineque posterius nigris, antennarum basi, pedibus elytrisque postice oblique testaceis; antennis crassiusculis apicem versus leviter incrassatis; thorace transverso posterius angustato, secundum marginem lateralem longitudinaliter, ante scutellum transversim profundius impresso, medio late canaliculato, elytrius hoc parum longioribus et latioribus; abdomine polito sublaevigato. - Long. $1 \frac{1}{2}$ lin.

Eine der kleineren Arten von gestreckter ziemlich gleichbreiter Gestalt, durch die Färbung und die kräftige Punktirung des Vorderkörpers im Gegensatz zu dem glänzend glatten Hinterleib in hohem Grade ausgezeichnet, rostroth, der Kopf und die hintere Hälfte des Hinterleibes - ohne scharfe Abgrenzung - schwarz, die Flügeldecken schwarzbraun, hinten vom Nahtwinkel an in schräger Richtung gegen den Seitenrand hin gelb, die Fühlerbasis, die Beine und der After rothgelb. Der Kopf ist schmäler als das Halsschild, breiter als lang, die Augen wenig vorstehend, die Stirn gewölbt, ziemlich dicht und grob punktirt. Die Fühler sind kräftig, nach der Spitze zu noch verdickt, länger als Kopf und Halsschild, das 3te Glied fast doppelt so lang als das 2te, das 4te und 5te quadratisch, die folgenden allmählig an Breite zunehmend, die vorletzten fast doppelt so breit als lang, das Endglied kurz, kaum so lang als 
das 9te und 10te zusammen, stumpf zugespitzt. Das Halsschild ist um mehr als die Hälfte breiter als lang, an den Seiten vorn schwach gerundet, nach hinten verengt, vor den scharf rechtwinkeligen Hinterecken unmerklich ausgerandet, am Hinterrande sanft gerundet, an den Vorderecken etwas niedergedrückt und stumpf zugerundet; oben ist es der Quere nach leicht gewölbt, längs des Seitenrandes bis in die Seiten des Hinterrandes hinein in etwas schräger Richtung eingedrückt, so dafs der Seitenrand etwas aufgebogen scharf erhaben erscheint, vor dem Schildchen mit einer breiten, kurzen Grube versehen, welche in einen breiten, sich allmählig verflachenden, vor der Spitze erlöschenden Längseindruck übergeht; seine Punktirung ist dicht und grob, rauhkörnig, seine Behaarung sparsam, kurz und fein. Die Flügeldecken sind wenig breiter und etwas länger als das Halsschild, nach rückwärts kaum erweitert, am Hinterrande vor den stumpf abgerundeten Hinterecken seicht ausgerandet, oben ziemlich flach, noch etwas dichter und gröber als das Halsschild, rauhkörnig punktirt und etwas dichter und deutlicher behaart. Der Hinterleib ist wenig schmäler als die Flügeldecken, nach der Spitze zu schwach verschmälert, oben auf den drei ersten Segmenten an der Basis der Quere nach eingedrückt, glatt, unpunktirt und unbehaart, nur an der Basis der einzelnen Ringe sparsam, an der des 5ten und 6ten Segments etwas dichter punktirt. Geschlechtsunterschiede treten an den 3 mir vorliegenden Stücken am Hinterleibe nicht hervor; bei allen dreien ist der Hinterrand des 7 ten oberen Segments breit abgerundet.

\section{Myrmedonia alternata n. sp.}

Elongata, sublinearis, nitida, rufo-testacea, capite, abdomine posterius elytrisque nigricantibus, his sutura anguste, apice latius rufo-testaceis; antennis apicem versus valde incrassatis; capite suborbiculato, thorace transverso basin versus angustato aequali elytrisque hoc longioribus et lateriobus crebrius fortiusque punctatis, abdomine glabro, laevigato. - Long. $1 \frac{1}{2}$ lin.

In Grölse, Gestalt und Färbung der vorhergehenden Art ähnlich, durch andere Skulptur und keulenförmig verdickte Fühler vornehmlich abweichend. Der Körper ist oben wenig gewölbt, glänzend, der Vorderkörper sparsam und kurz, anliegend behaart, der Hinterleib glatt; der Kopf, die 3 letzten Hinterleibssegmente und die Flügeldecken sind schwärzlich, die letzteren an der Naht schmal, am Hinterrande breit rothgelb gesäumt, das Halsschild, die vorderen Hinterleibsringe und die Fühler und Beine sind roth- 
gelb. Der Kopf ist rundlich, fast so lang als breit, schmäler als das Halsschild, oben deutlich ziemlich sparsam punktirt. Die Fühler sind kaum länger als Kopf und Halsschild, nach der Spitze stark keulenartig verdickt, das erste Glied lang und ziemlich dünn, auch das 2te und 3te Glied schlank und gestreckt, das 3te etwas kürzer als das 2te, das 4te schon quer, die folgenden allmählig stark verbreitert, die vorletzten mehr als $3 \mathrm{mal}$ so breit als lang, das Endglied dick, so lang als die 3 vorhergehenden zusammen, an der Spitze abgerundet. Das Halsschild ist um mehr als ein Drittel breiter als lang, an den Seiten vorn gerundet, nach rückwärts verengt, mit abgerundeten Vorder- und Hinterecken, oben der Quere nach leicht gewölbt, mälsig dicht, ziemlich kräftig punktirt, vor dem Schildchen zuweilen mit einem schwachen Quergrübchen versehen. Die Flügeldecken sind um ein Drittel länger und breiter als das Halsschild, am Hinterrande neben den spitz vorstehenden Hinterecken etwas ausgeschweift, etwas stärker und sparsamer als das Halsschild punktirt. Der Hinterleib ist glänzend glatt, das 7 te obere Segment fein und undeutlich punktirt.

Geschlechtsunterschiede treten nicht deutlich hervor; bei dem einen meiner 3 Exemplare ist der Hinterrand des rorletzten unteren Segments in der Mitte ausgerandet; es scheint ein 우 zu sein.

\section{Aleochara (Baryodma) picipennis n. sp.}

Fusiformis, nigra, nitida, elytris piceis, antennarum basi testacea, pedibus piceo-testaceis; thorace parcius subtilius, elytris hoc brevioribus confertissime asperatim, abdomine crebrius sat fortiter punctatis. - Long. $1 \frac{1}{3}$ lin.

Von der Gestalt der Al. bipunctata, aber 3 mal kleiner, nach vorn und hinten gleichmälsig verengt, glänzend schwarz, mit einfarbig pechbraunen, matteren Flügeldecken. Der Kopf ist klein, stark herabgebogen, sparsam, ziemlich fein punktirt und nur mäfsig fein anliegend grau behaart. Die Fühler sind kräftig, fast so lang als Kopf und Halsschild, bis zur Mitte hin verdickt, von da bis zur Spitze fast gleichbreit, schwarz, die 3 ersten Glieder rothgelb, das 2te und 3te ziemlich schlank, gleichlang, das 4te schon etwas breiter als lang, das 5te noch um die Hälfte breiter, die folgenden an Länge und Breite kaum verschieden, stark transversal, das Endglied länger als die 2 vorhergehenden zusammen, vorn zugespitzt, vor der Mitte deutlich knotig abgesetzt. Das Halsschild ist hinten so breit als die Flügeldecken, nach vorn stark verengt, mit niedergedrückten stumpf abgerundeten Vorderecken, an den Seiten und 
hinten gerundet, am Hinterrand beiderseits undeutlich ausgerandet, oben gewölbt, ziemlich sparsam und fein, wie der Kopf punktirt und behaart. Die Flügeldecken sind etwas kürzer als das Halsschild, an den Hinterecken abgerundet, oben äufserst dicht, kräftig, reibeisenartig punktirt. Der Hinterleib ist vorn so breit als das Halsschild, nach hinten gleichmäfsig und stark verengt, oben dicht und stark, auf dem 6ten Segment etwas weniger dicht punktirt, alle Punkte von binten eingestochen, mäfsig fein anliegend behaart, am Hinterrand der beiden letzten Ringe rothbraun. Die Beine sind gelbbraun, die Tarsen heller.

Beim $\sigma^{\tau}$ ist der Hinterrand des 7 ten oberen Ringes seicht ausgerandet und fein und dicht crenulirt.

Zwei Männchen.

\section{Gyrophaena angularis n. sp.}

Rufo-testacea, polita, capite, elytrorum angulis posticis abdomineque posterius nigris; thorace brevissimo, valde transverso, lateribus rotundato, disco 4-punctato, elytris hoc duplo longioribus parce indistincte punctatis, abdomine subtilissime alutaceo subopaco. Long. 1 lin.

Mas: Abdominis segmento superiore $7^{0}$ apicem versus angustato, apice ipso truncato denticulisque quatuor, mediis minoribus approximatis, ornato.

Von der Gestalt und Gröfse der G. affinis, glänzend rothgelb, mit gleichfarbigen Fühlern und Beinen, der Kopf, die Hinterecken der Flügeldecken und die 4 letzten Hinterleibssegmente schwarz. Der Kopf ist etwas schmäler als das Halsschild, mit grofsen vorgequollenen Augen, welche die ganzen Seiten des Kopfes einnehmen, die Stirn kaum gewölbt, an den Seiten einzeln, schwach und undeutlich punktirt, hinter dem Fühleransatze am Innenrande der Augen jederseits mit einem rundlichen seichten Grübchen versehen, oben mit wenigen vereinzelten abstehenden schwarzen Haaren besetzt. Die Fühler sind dünn, so lang als Kopf und Halsschild, die einzelnen Glieder an der Spitze mit abstehenden Härchen besetzt, das erste sehr gestreckt, auch die 2 folgenden sehr schlank und dünn, das 2 te um die Hälfte länger und stärker als das 3te, das 4te etwas stärker aber kürzer als das 3te, das 5te doppelt so breit als das 4te, wie die folgenden verkehrt kegelförmig, so lang als breit, diese nehmen an Länge kaum ab, an Breite kaum zu, alle sind etwa so lang als breit, das Endglied ist etwas kürzer als die 2 vorletzten, stumpf zugespitzt. Das Halsschild ist sehr kurz und breit, etwa 
$2 \frac{1}{2}$ mal so breit als lang, vorn gerade abgeschnitten, an den Seiten und dem Hinterrande gerundet, oben schwach gewölbt, wie der Kopf mit einzelnen abstehenden Härchen besetzt, auf der Mitte der Scheibe mit 4 ins Viereck gestellten Punkten geziert, von denen die vorderen einander etwas näher stehen als die hinteren. Die Flügeldecken sind etwas breiter und doppelt so lang als das Halsschild, oben flachgedrückt, mit vereinzelten meist undeutlichen Punkten und sparsamen, kaum sichtbaren, grauen anliegenden Härchen besetzt. Der Hinterleib ist oben äufserst fein lederartig gewirkt, daher weniger glänzend als der Vorderkörper, schwarz, die 3 ersten Segmente hell rothbraun.

Beim $\sigma^{7}$ ist das 7 te obere Hinterleibssegment nach der Spitze verengt, der Hinterrand desselben abgestutzt und mit 4 Zähnchen geziert, von denen die 2 mittleren einander ganz nahe gerückten viel kleiner und feiner sind als die beiden seitlichen stumpfen und breiteren.

Ein einziges $\sigma^{\top}$.

Pygostenus microcerus $\mathrm{Kr}$. Etwa ein Dutzend in der Gröfse sehr variirende Exemplare.

Tanygnathus varicornis Woll. In grofser Anzabl.

Philonthus quisquiliarius Gyll. Ebenfalls zahlreich, ausschliefslich die Normalform mit dunkelgrünen Decken.

\section{Philonthus (Rabigus) nigriceps n. sp.}

Elongatus, gracilis, rufo-testaceus, capite nigro, abdomine rufofusco, antennis fuscis basi apiceque pedibusque testaceis; capite oblongo thorace angustiore, hoc latiludine longiore antrorsum subangustato seriebus dorsalicus 5 punctatis, elytris thorace longioribus abdomineque creberrime subtiliter punctatis. - Long. $1 \frac{3}{4}-2$ lin.

Mas: Tarsis anterioribus leviter dilatatis, abdominis segmento penultimo ventrali apice acute triangulariter exciso.

Von der schlanken gestreckten Gestalt des Ph. pullus, ziemlich gewölbt, rothgelb, die Flügeldecken an der Basis und längs der Naht zuweilen bräunlich angelaufen, der Kopf schwarz, der Hinterleib braunroth, gegen die Spitze zu etwas heller, die Fühler hellbraun mit hellerer Basis und Spitze, die Beine hellgelb. Der Kopf ist länglich, etwas schmäler als das Halsschild, nach hinten schwach verengt, oben wenig gewölbt, an den Seiten neben dem Innenrande der Augen und in der Schläfengegend mit wenigen ziemlich feinen Punkten und sparsamen abstehenden, langen schwarzen Haaren besetzt, in der Mitte ganz glatt. Der Mund und die 
Taster sind gelblichroth, das Endglied der Kiefertaster konisch, vorn scharf zugespitzt. Die Fühler sind bräunlich, die drei ersten Glieder und das letzte hellgelb, zuweilen einfarbig rothgelb, so lang als Kopf und Halsschild, nach der Spitze zu äufserst schwach verdickt, die ersten Glieder sehr gestreckt, das 3te etwas länger als das 2te, von den folgenden die ersten länger, die vorletzten noch so lang als breit, das Endglied um die Hälfte länger als das 10te, innen schräg ausgerandet. Das Halsschild ist wenig länger als an der Basis breit, nach vorn sanft verengt, an den Seiten kaum, am Hinterrande leicht gerundet mit breit abgerundeten Hinter- und niedergebogenen zugerundeten Vorderecken, oben gewölbt, auf der Scheibe mit 2 Längsreihen von je 5 gleichweit von einander abstehenden feinen Punkten versehen, wie der Kopf sparsam abstehend schwarz behaart. Die Flügeldecken sind unmerklich breiter als der Hinterrand des Halsschildes und wenig länger als dasselbe, an der Spitze schräg nach dem Nahtwinkel zu abgestutzt, oben fein und äufserst dicht punktirt und anliegend grau behaart. Der Hinterleib ist so breit als die Flügeldecken, nach der Spitze zu leicht verschmälert, fein und sehr dicht punktirt und behaart, auf dem 7 ten Segment sparsam punktirt.

Beim $0^{\pi}$ sind die Vordertarsen etwas mehr als beim $q^{2}$ erweitert, und der Hinterrand des vorletzten Ventralsegmentes ist in der Mitte scharf dreieckig ausgeschnitten.

In zahlreichen Exemplaren aufgefunden.

\section{Platyprosopus longicollis n. $\mathrm{sp}$.}

Elongatus, angustus, linearis, dilute rufo-brunneus, capite abdomineque piceo-rufis, antennis pedibusque ferrugineis, dense aureopubescens, thorace glabro; capite oblongo thorace fere longiore dense subtiliter punctato, hoc latitudine longiore medio lateribusque utrinque parce fortiter seriatim punctato; elytris thorace parum longioribus dense, abdomine creberrime subtiliter punctatis. - Long. $3 \frac{1}{2}$ lin.

Von langgestreckter, schmaler, gleichbreiter Gestalt, wenig gewölbt, hell rothbraun, das Halsschild etwas lebhafter roth als die Flügeldecken, der Kopf und Hinterleib kastanienbraun, letzterer mit breit rostrothem Hinterrand der Segmente, die Fühler und Beine hell rostroth, - Kopf, Flügeldecken und Hinterleib dicht und fein punktirt und dicht nicht allzufein goldge!b behaart, daher wenig glänzend, das Halsschild glatt, unbehaart, lebhaft glänzend. Der Kopf ist länglich, fast etwas länger und so breit als das Halsschild, nach hinten nicht verengt, an den Seiten gerade, nur am Ueber- 
gang in den Hals schwach eingeschnürt, oben dicht und fein, an den Seiten sehr dicht runzelig punktirt, eine wenig deutlich begrenzte schmale Längslinie in der Mitte glatt, aufser der dichten goldgelben Behaarung noch mit einigen wenigen längeren abstehenden Haaren besetzt. Die Mandibeln sind schwarz, die Taster rothgelb. Die fadenförmigen Fühler sind um die Hälfte länger als der Kopf, das 2te Glied um die Hälfte kürzer als das 3te, von den folgenden die ersten $1 \frac{1}{2} \mathrm{mal}$, die vorletzten noch gut so lang als breit, das Endglied wenig länger als das 10te, an der Spitze schräg abgeschnitten. Das Halsschild ist etwas länger als breit, vorn und hinten gerade abgestutzt, auch an den Seiten ziemlich gerade mit abgerundeten Hinterecken, oben im Grunde ziemlich dicht, äufserst fein, kaum sichtbar punktirt, so dafs der Glanz der Oberfläche kaum gemindert wird, hart am Seitenrande mit untermischten gröberen und feineren Punkten besetzt, auf der Scheibe mit vier Längsreihen von länglichen groben und tiefen Punkten geschmückt, 2 mittleren mit je 5 und 2 seitlichen nach vorn abgekürzten Reihen mit je vier Punkten, - glatt, unbehaart, nur am Seitenrande mit wenig dicht stehenden nicht allzufeinen Härchen besetzt, unter welche sich einige längere abstehende Haare mischen. Die Flügeldecken sind kaum breiter und etwas länger als das Halsschild, dicht und fein punktirt und behaart, an den Seiten nahe der Schulter und im hinteren Drittheil mit zwei abstehenden Borstenhaaren besetzt. Der Hinterleib ist nur sehr wenig scbmäler als die Flügeldecken, bis unmittelbar vor die Spitze gleichbreit, oben äufserst dicht punktirt und behaart. Die Beine sind hell rostroth.

Ein einziges Exemplar.

\section{Doicaon castaneus n. $\mathrm{sp}$.}

Elongatus, sublinearis, densius griseo-pubescens, nitidulus, castaneus, ore antennis pedibusque rufo-testaceis, abdominis segmentorum marginibus anoque ferrugineis; capite subrotundato parcius, thorace subquadrato elytrisque hoc paullo longioribus et latioribus dense subtilius, abdomine crebrius subtiliter punctatis. - Long. $3 \frac{1}{2}$ lin.

Mas: Abdominis segmentis ventralibus quinto sextoque medio longitudinaliter latiusque profunde impressis, hoc apice medio emarginato, septimo per tolam fere longitudinem anguste fisso, fissurae marginibus relevatis, apice subtriangulariter exciso.

Fem.: Abdominis segmento $7^{0}$ ventrali apice producto, cochlearis instar excavato, apice summo rotundato. 
In der gestreckten, gleichbreiten Gestalt unserem Lathrobium elongatum und geminum sehr ähnlich, aber dieser Gattung angehörig, kastanienbraun mit rothgelben Fühlern und Beinen, ziemlich glänzend, fein und mäfsig dicht grau behaart. Der Kopf ist rundlich, so breit als das Halsschild, ein wenig breiter als lang, oben ziemlich sparsam kräftig punktirt, ein undeutlich begrenzter Raum in der Mitte glatt, unten noch kräftiger und tiefer punktirt als auf der Oberseite. Die fadenförmigen Fühler sind anderthalbmal so lang als der Kopf, das 3te Glied fast doppelt so lang als das 2te, von den folgenden die ersten gut um die Hälfte länger als breit, die vorletzten noch so lang als breit. Das Halsschild ist quadratisch, kaum länger als breit, an den Seiten gerade, an allen Ecken abgerundet, oben gewölbt, dicht und mälsig fein punktirt, in der Mitte mit einer schmalen durchziehenden glatten Längslinie. Die Flügeldecken sind etwas breiter und um ein Drittel länger als das Halsschild, wie dieses punktirt und behaart. Der Hinterleib ist vorn nur sehr wenig schmäler als die Flügeldecken, kaum dichter aber feiner als diese punktirt, an der Basis der vorderen Segmente kastanienbraun, in der hintern Hälfte derselben und auf den zwei letzten Ringen hell rothbraun.

Beim $\sigma^{\top}$ ist das 5te untere Segment in der hintern Hälfte, das 6te der ganzen Länge nach tief und breit eingedrückt, das letztere in der Mitte des Hinterrandes ausgerandet, das 7te hinten dreieckig ausgeschnitten, von der Spitze des Aussschnittes an bis fast zur Basis schmal und scharf gespalten, die Ränder der Spalte aufwärts geschlagen und erhaben.

Beim $q$ ist das 7 te untere Segment lang vorgezogen, gegen die Spitze hin löffelförmig ausgehöhlt, an der Spitze. selbst abgerundet. - Diese Art steht dem D. angolense am nächsten, welches Quedenfeldt irrthümlich als ein Lathrobium beschrieben hat.

Eine Reihe von Exemplaren.

\section{Dolicaon limbatus n. sp.}

Elongatus, linearis, parallelus, nitidus, niger, thorace abdomineque supra nigro-piceis, elytrorum sutura apiceque, abdominis segmentorum marginibus anoque ferrugineis, antennis pedibusque testaceis; capite quadrato parcius, thorace oblongo elytrisque hoc longioribus crebrius sat fortiter, abdomine minus dense subtiliter punctatis. Long. $2 \frac{1}{2}-2 \frac{2}{3}$ lin.

Mas: Abdominis segmento inferiore $6^{0}$ apice late indistincte emarginato, $7^{0}$ triangulariter exciso et longitudinaliter fisso, fissurae marginibus acute relevatis. 
Ganz von der gestreckten gleichbreiten Gestalt der vorhergehenden Art, aber viel kleiner und anders gefärbt. Der Körper ist ziemlich gewölbt, glänzend, der Vorderkörper sparsam, der Hinterleib dichter und deutlicher graugelb behaart. Der Kopf und die Flügeldecken sind tief schwarz, letztere an der Naht und dem Hinterrande rostroth, das Halsschild und der Hinterleib dunkel pechbraun, letzterer mit schmal rostgelbem Hintersaum der einzelnen Ringe und mit rostrothem After, die Fühler und Beine sind hell gelbroth. Der Kopf ist quadratisch, so lang als breit, so breit als das Halsschild, nach hinten nicht verengt, mit stumpfen Hinterecken, oben etwas gewölbt, sparsam und kräftig punktirt, ein breiterer Längsraum in der Mitte glatt. Die Fühler sind etwa doppelt so lang als der Kopf, nach der Spitze zu leicht verdickt, das 3te Glied um die Hälfte länger als das 2te, von den folgenden die ersten länger als breit, die vorletzten breiter als lang, das Endglied kurz. Das Halsschild ist etwas länger als breit, an den Seiten gerade, an den Ecken abgerundet, oben etwas dichter als der Kopf punktirt, mit einer breiten glatten Längslinie in der Mitte. Die Flügeldecken sind kaum breiter und etwas länger als das Halsschild, wie dieses punktirt und behaart. Der Hinterleib ist fast so breit als die Flügeldecken, oben wenig dicht, ziemlich fein und seicht punktirt. Die Beine sind hell gelblichroth.

Beim $\sigma^{7}$ ist das 7 te untere Hinterleibssegment am Hinterrande scharf dreieckig ausgeschnitten, von der Spitze des Ausschnittes an bis zum vorderen Drittheil schmal und scharf gespalten, die Ränder der Spalte aufgeworfen und scharf erhaben.

Vier Stücke.

Lathrobium caffer Boh. Mehrere Stücke.

Lathrobium subseriatum n. $\mathrm{sp}$.

Elongatum, lineare, subdepressum, densius pubescens, anterius sat fortiter punctatum, nitidum, piceum, capite nigro, abdominis segmentorum marginibus, ano, antennis pedibusque rufs; capite thoraceque quadratis, parallelis, illo parce hoc crebrius punctato, linea longitudinali media lata laevi; elytris thorace dimidio fere longioribus densius subseriatim, abdomine minus crebre subtilius punctatis. - Long. 3 lin.

Mas: Abdominis segmento inferiore penultimo profunde subtriangulariter exciso.

Von der gestreckten gleichbreiten Gestalt der vorhergehenden Art, oben weniger gewölbt, etwas flachgedrückt, ziemlich dicht, 
nicht besonders fein, etwas abstehend graugelb behaart, glänzend, pechbraun mit schwarzem Kopfe, der Hinterrand der einzelnen Segmente, die Hinterleibsspitze, die Fühler und Beine röthlich. Der Kopf ist quadratisch, so lang als breit, so breit als das Halsschild, an den Seiten gerade mit stumpfen Hinterecken, oben sparsam, kräftig, an den Seiten etwas dichter und runzelig punktirt, in der Mitte in geringerer Ausdehnung glatt. Die Fühler sind schlank, fast so lang als Kopf und Halsschild, das 3te Glied um die Hälfte länger als das 2te, alle Glieder länger als breit, an der Spitze mit längeren abstehenden Haaren besetzt. Das Halsschild ist etwas länger als breit mit geraden parallel verlaufenden Seiten, stumpfen Vorder- und abgerundeten Hinterecken, oben ebenso kräftig, etwas dichter als der Kopf punktirt, in der Mitte von einer ziemlich breiten glatten Längslinie durchzogen. Die Flügeldecken sind wenig breiter und fast um die Hälfte länger als das Halsschild, neben der Naht der Länge nach eingedrückt, etwas weniger stark und tief als das Halsschild punktirt, die Punkte auf dem Rücken in mehr weniger regelmäfsigen Längsreihen stehend, gegen die Spitze hin und auf dem umgeschlagenen Seitenrande verworren. Der Hinterleib ist etwas schmäler als die Flügeldecken, oben nicht dicht, ziemlich fein und seicht punktirt.

Beim $\sigma^{\lambda}$ ist der Hinterrand des vorletzten unteren Hinterleibssegments in der Mitte tief dreieckig ausgeschnitten, die Spitze des Dreiecks abgerundet.

Ein Pärchen.

\section{Lathrobium incertum n. sp.}

Praecedenti simillimum, duplo majus, depressiusculum, nigrum, elytris castaneis, antennis pedibus anoque ferrugineis; antennis elongatis gracillimis, capite thorace latiore antrorsum, hoc basin versus angustato quadratis, elytris subseriatim punctatis. - Long. $4 \frac{1}{2}$ lin.

Mas: Latet.

In Gestalt und Punktirung. mit der vorhergehenden Art fast vollkommen übereinstimmend, aber mehr als doppelt so grols, in folgenden Punkten vornehmlich abweichend.

Die Färbung ist eine dunklere, Kopf, Halsschild und Hinterleib sind schwarz, letzterer mit rothbraunem Hinterrand der Segmente und rothem After. Die Fühler sind gestreckter und verhältnifsmälsig dünner und schlanker, zurückgelegt über den Hinterrand des. Halsschildes hinausreichend, die einzelnen Glieder länger und gestreckter als bei der vorhergehenden Art. Der Kopf ist 
breiter als das Halsschild, so breit als die Flügeldecken, nach vorn verschmälert, während das Halsschild nach rückwärts verengt und die glatte Mittellinie desselben hinten erhaben ist. Die kastanienbraunen, gegen die Hinterecken zu schwärzlichen Flügeldecken wie der Hinterleib sind wie bei der vorhergehenden Art geformt und punktirt.

Zwei Weibchen. Bei dem einen unausgefärbten Stücke ist der Körper rothbraun, der Kopf etwas dunkler.

\section{Cryptobium cribripenne n. sp.}

Nigrum, subnitidum, antennis fuscis basi apiceque testaceis, pedibus pallide flavis, anterius confertissime minus subtiliter punctatum; capite oblongo thorace latiore, hoc elongato, medio per totam longitudinem subcarinato, elytris thorace longioribus duploque latioribus, abdomine dense subtiliter punctato. - Long. $2 \frac{1}{2}$ lin.

Mas: Abdominis segmento inferiore $3^{0}$ ante apicem lamina minuta transversa brevissima apice truncata denticulataque instructo, $4^{0}$ callo transverso polito ornato, $6^{0}$ medio fovea oblonga profunde impresso, $7^{0}$ apice subrotundatim emarginato.

Durch die gleichmäfsig dichte und ziemlich kräftige Punktirung des ganzen Vorderkörpers, wodurch der Glanz desselben erheblich herabgemindert wird, besonders ausgezeichnet, einfarbig schwarz, mit hellröthlichen in der Mitte bräunlichen Fühlern und hellgelben Beinen, oben ziemlich dicht und fein grau behaart. Der Kopf ist länglich, etwas breiter als das Halsschild, an den Seiten fast gerade, an den Hinterecken stark abgerundet, oben äufserst dicht und ziemlich kräftig, gegen den Mund zu weniger dicht punktirt, von den Augen an nach vorn braunroth; die Mandibeln und die Maxillartaster ebenfalls braunroth, letztere an der Spitze hellgelb. Die Augen stehen vor der Mitte des Kopfes. Die Fühler sind röthlich, das erste Glied an der Spitze und die 5 folgenden bräunlich, diese mit heller Basis der einzelnen Glieder; sie sind kürzer als Kopf und Halsschild, das 2te und 3te Glied schlank, das 3te nicht ganz um die Hälfte länger als das 2te, von den folgenden die ersten entschieden länger als breit, die vorletzten noch so lang als breit, das Endglied kurz, kaum länger als das 10te, an der Spitze abgestutzt. Das Halsschild ist um die Hälfte länger als breit, hinten fast nur halb so breit als die Flügeldecken, an den Seiten fast gerade, hinten ganz unmerklich, vorn etwas mehr eingezogen mit stark niedergebogenen breit abgerundeten Vorder- und stumpflichen Hinterecken, am Hinterrande gerade abgeschnitten, oben ziemlich 
gewölbt, wie der Kopf punktirt, in der Mitte der ganzen Länge nach von einer glänzend glatten, leicht kielförmig erhabenen Längslinie durchzogen. Die Flügeldecken sind um ein Drittel länger als das Halsschild, fast noch dichter als dieses punktirt. Der Hinterleib ist kaum weniger dicht, aber viel feiner als der Vorderkörper punktirt und glänzender als dieser, der Hinterrand der letzten Segmente zuweilen rothbraun. Die Beine sind blafsgelb, die Hüften hell röthlichbraun.

Beim $\sigma^{\top}$ hat das 3te untere Hinterleibssegment vor der Mitte des Hinterrandes ein kleines, kurzes, niedriges, aufrecht stehendes, oben abgestutztes und gezähneltes Plättchen, an dessen Stelle bei dem folgenden Segment eine glänzend glatte Querschwiele tritt; das 6te ist in der Mitte von einer tiefen, im Grunde spiegelglatten Längsgrube durchzogen, das 7 te am Hinterrande dreieckig ausgerandet mit abgerundeten Vorder- und Seitenecken des Ausschnittes.

Wenige Exemplare.

\section{Cryptobium apicale n. sp.}

Piceum, nitidum, antennis, elytrorum humeris apiceque latius, abdominis segmentorum marginibus anoque rufis, pedibus pallide testaceis; capite oblongo-subovato thoracis latitudine crebrius, hoc lateribus crebre fortiter, elytris confertim fortius, abdomine dense subtiliter punctatis. - Long. $2 \frac{1}{2}$ lin.

Mas: Abdominis segmento inferiore $6^{0}$ medio apice leviter emarginato, $7^{0}$ subrotundatim inciso.

Pechbraun, glänzend, mälsig dicht und fein schwarzgrau behaart, die Fühler, ein schmaler Hintersaum der Segmente und der After, die Schultergegend und eine gegen den Seitenrand hin sich verbreiternde Binde an der Spitze der Flügeldecken hell rothbraun, die Beine blafsgelb, ihre Hüften röthlichbraun. Der Kopf ist kaum breiter als das Halsschild, annähernd eiförmig, oben wenig gewölbt, ziemlich dicht, nicht fein aber oberflächlich, etwas runzelig punktirt, die Punkte gegen den Mund zu aus gröberen und feineren gemischt, mit kürzeren anliegenden schwarzgrauen und sparsamen längeren abstehenden schwarzen Haaren besetzt. Die Augen stehen vor der Mitte des Kopfes. Die Mandibeln sind pechbraun, die Taster rothgelb. Die Fühler sind etwas kürzer als Kopf und Halsschild, schlank, röthlich, die 5 ersten Glieder an der Spitze pechbraun, das 3te Glied um die Hälfte länger als das 2te, von den folgenden die ersten fast doppelt so lang, die vorletzten noch etwas länger als breit, das Endglied kurz, an der Spitze abgeschnitten und 
plötzlich zugespitzt. Das Halsschild ist um ein Drittel schmäler als die Flügeldecken, nicht ganz um die Hälfte länger als breit, an den Seiten fast gerade, vorn unmerklich mehr als hinten eingezogen, oben gewölbt, dicht, grob und tief punktirt, mit einer breiten spiegelglatten Mittellinie, mit sparsamen abstehenden schwarzen Haaren besetzt. Die Flügeldecken sind um ein Drittel länger als das Halsschild, hinten in der Mitte gemeinschaftlich ausgerandet, an den Hinterecken breit abgerundet, oben etwas flachgedrückt, sehr dicht und ziemlich kräftig, runzelig, viel dichter und feiner als das Halsschild punktirt, dicht schwärzlich behaart, die Schultergegend bis gegen das Schildchen hin braunroth, eine an der Naht schmale, gegen den Seitenrand hin sich verbreiternde Binde an der Spitze heller roth. Der Hinterleib ist ziemlich dicht, fein punktirt. Die Unterseite ist fast einfarbig roth.

Beim $\widehat{\sigma}$ ist der Hinterrand des 6 ten unteren Segments breit und seicht ausgerandet, das 7 te an der Spitze mälsig tief rundlich ausgeschnitten mit einer glänzend glatten länglichen Stelle oberhalb des Ausschnittes.

Ein einziges $ぇ$.

\section{Cryptobium rugiceps n. sp.}

Sublineare, subdepressum, nigrum, nitidulum, capite antrorsum, thorace, elytrorum humeris suturaque rufo-piceis, abdominis segmentorum marginibus anoque rufs, antennis pedibusque ferrugineis; capite subquadrato ad oculos usque rugis subtilibus transversis confertissime obsito, apice confertim rugulose punctato; thorace oblongoquadrato lateribus, elytris hoc longioribus dense minus subtiliter, abdomine minus crebre punctatis. - Long. $2 \frac{1}{2}$ lin.

Mas: Latet.

Von ziemlich gleichbreiter, etwas flachgedrückter Gestalt, durch die eigenthümliche Skulptur des Kopfes besonders ausgezeichnet, mälsig glänzend, ziemlich dicht grau behaart, schwarz, der Kopf vor den Augen, das Halsschild, die Schultern und die Naht der Flügeldecken rothbraun, die Ränder der Hinterleibssegmente und der After etwas heller roth, die Fühler und Beine rostroth. Der Kopf ist etwas breiter als das Halsschild, vom Hinterrande bis zu den Augen querquadratisch mit stumpf abgerundeten Hinterecken, vor den Augen plötzlich verschmälert und mit parallelen Seiten zum Vorderrand verlaufend, hinten bis zu den Augen mit dichten feinen Querrunzeln überzogen, vorn dicht, etwas runzelig punktirt. Die Mandibeln sind rothbraun, die Taster rostroth. Die Augen 
liegen ziemlich in der Mitte der Seiten des Kopfes. Die Fühler sind kürzer als Kopf und Halsschild, einfarbig rostroth, die ersten Glieder gestreckt, das 2te und 3te Glied gleichlang, von den folgenden die ersten um die Hälfte länger als breit, die vorletzten schwach transversal, das Endglied kurz, vorn abgestutzt. Das Halsschild ist länglich quadratisch, um ein Drittel länger als breit, mit fast gleichlaufenden Seiten, stumpfen Vorder-und kurz abgerundeten Hinterecken, dicht, nur mälsig fein punktirt, in der Mitte mit einer schmalen durchgehenden hinten leicht erhabenen Längslinie. Die Flügeldecken sind um ein Drittel länger und breiter als das Halsschild und wie dieses punktirt. Der Hinterleib ist vorn pechbraun, von der Mitte an schwarz mit rothem Hinter- und Seitenrand der einzelnen Segmente und mit rothem After, oben nicht dicht aber fein punktirt. Die Beine sind rostroth.

Das $\sigma^{\top}$ ist mir unbekannt geblieben.

Ein einziges + .

\section{Stilicus rubellus n. sp.}

Rufescens, abdomine apicem versus elytrisque obscure castaneis, his apice, antennis pedibusque cum coxis testaceis; capite elytris latiore suborbiculato thoraceque lateribus anterius angulato omnium creberrime subtilissimeque punctatis, opacis; elytris crebrius subtiliter punctatis punctisque pluribus majoribus subseriatim positis ornatis, nitidis; abdomine subtilissime punctato tenuissimeque griseo-pubescente. - Long. $1 \frac{1}{2}$ lin.

Mas: Abdominis segmentis ventralibus sexto septimoque apice late leviter emarginatis.

Von der Gestalt des St. orbiculatus, aber kleiner, durch Färbung und Skulptur gleich ausgezeichnet, mattröthlich, der Hinterleib gegen die Spitze zu und die glänzenden Flügeldecken dunkel kastanienbraun, der breite Hinterrand der ersteren, die Fühler und die Beine sammt den Hüften gelblich. Der Kopf ist um ein Geringes breiter als die Flügeldecken, rundlich, oben äufserst dicht und fein punktirt, matt. Die Fühler sind etwas länger als der Kopf, das 2te und 4te Glied gleichlang, doppelt so lang als breit, das 3te um die Hälfte länger als die beiden einschliefsenden, von den folgenden die ersten so lang als breit, die vorletzten transversal, das Endglied lang eiförmig zugespitzt. Das Halsschild ist etwas schmäler als die Flügeldecken, an den Seiten vor der Mitte winkelig erweitert, von da in einwärts gebogener Linie rasch und stark nach vorn verengt, nach hinten sanfter in gerader Linie verschmälert, 
am Hinterrande gerade abgestutzt, oben wie der Kopf punktirt, matt. Die Flügeldecken sind doppelt so breit als der Hinterrand des Halsschildes und fast um die Hälfte länger als dasselbe, mäfsig dicht fein punktirt, mit 2 unregelmäfsigen Längsreihen von je $4-5$ gröberen tieferen Punkten. Der Hinterleib ist dicht und äufserst fein punktirt, äufserst fein und zart, anliegend grau behaart.

Beim $\widetilde{c}$ ist das 6 te und 7 te untere Hinterleibssegment an der Spitze breit und seicht ausgerandet.

Ein einziges $\sigma^{\top}$

\section{Sunius bivittatus n. sp.}

Elongatus, sublinearis, subtiliter cinereo-pubescens, rufus, antennis, pedibus elytrisque testaceis, his vitta oblonga laterali lata abdominisque segmento $6^{0}$ nigris; capite elytrorum latitudine thoraceque breviter obovato dense reticulato-punctatis, opacis, elytris thorace longioribus nitidis crebre fortiter, abdomine minus crebre subtilius punctatis. - Long. $1 \frac{2}{3}$ lin.

Mas: Abdominis segmento inferiore $6^{0}$ apice medio rotundatim emarginato, $7^{0}$ acute triangulariter exciso.

Von gestreckter, ziemlich gleichbreiter Gestalt, wenig gewölbt, mäfsig dicht grau behaart, roth, die Fühler, die Beine und die Flügeldecken gelblich, eine breite, längs des Seitenrandes bis zum hintern Drittel der Flügeldecken herablaufende und die Hälfte der Deckenbreite einnehmende Binde und das 6te Hinterleibssegment schwarz. Der Kopf ist so breit als die Flügeldecken, länglich quadratisch, hinten fast gerade abgeschnitten, an den Hinterecken abgerundet, oben ziemlich flach, dicht und fein netzförmig punktirt, matt, unten mäfsig dicht, ziemlich kräftig punktirt. Die Fühler sind fadenförmig, etwas kürzer als Kopf und Halsschild, alle Glieder länger als breit. Das Halsschild ist etwas schmäler als die Flügeldecken, nur wenig länger als breit, verkehrt kurz-eiförmig, an den Seiten vor der Mitte gerundet erweitert, nach hinten sanft verengt, am Hinterrande schwach gerundet, oben wenig gewölbt, wie der Kopf punktirt, matt, am Seitenrande gleich dem Kopfe mit einzelnen wenigen schwarzen abstehenden Haaren besetzt. Die Flügeldecken sind wenig breiter und fast um die Hälfte länger als das Halsschild, oben dicht und kräftig, leicht körnig punktirt. Der Hinterleib ist schmäler als die Flügeldecken, nach der Basis zu leicht verengt, oben nur mäfsig dicht, fein punktirt. Die Beine mit sämmtlichen Hüften sind hellgelb. 
Beim $\widetilde{\sigma}$ ist der Hinterrand des 6 ten unteren Hinterleibsringes in der Mitte ausgerandet, mit einer dreieckigen eingedrückten Stelle hinter der Ausrandung, das 7 te an der Spitze scharf dreieckig ausgeschnitten.

Eine Reihe von Exemplaren.

Sunius melanurus Küst. Wenige Stücke.

\section{Sunius simillimus n. sp.}

Rufus, elytris testaceis, macula posteriore sublaterali nigra, abdomine rufo-fusco segmento $6^{0}$ nigro, antennis pedibusque pallide flavis; capite subquadrato elytrorum latitudine thoraceque obovato dense subtilius reticulato-punctatis; elytris thorace longioribus creberrime fortius, abdomine crebrius minus subtiliter punctatis. Long. $1 \frac{2}{3}$ lin.

In Färbung und Gestalt dem S. melanurus sehr äbnlich, etwas weniger flacb, durch das längere Halsschild und die gefleckten Flügeldecken leicht zu unterscheiden, gestreckt, mäfsig gewölbt, graugelb anliegend behaart, wenig glänzend, röthlich, die Flügeldecken gelblich, mit einem schwarzen Flecken, welcher in der hintern Hälfte derselben an den Seiten gelegen ist, jedoch den umgeschlagenen Seitenrand nicht berührt, der Hinterleib bräunlichroth mit schwarzem, an der Spitze schmal hellgelbem 6ten Segment, die Fühler und Beine blafsgelb. Der Kopf ist von der Breite der Flügeldecken, so breit als lang, von den Augen an nach hinten unmerklich verengt, am Hinterrand wenig, an den Hinterecken deutlicher gerundet, oben dicht und ziemlich fein netzförmig punktirt, in der Mitte gewölbt, nach hinten und noch mehr nach vorn abgeflacht, an den Seiten mit wenigen abstehenden schwarzen Haaren besetzt. Die Fühler sind fadenförmig, etwas länger als der Kopf. Das Halsschild ist verkehrt eiförmig, etwas länger als breit, an der breitesten Stelle um ein Drittel schmäler als die Flügeldecken, an den Seiten vor der Mitte gerundet erweitert, nach hinten stark verengt, oben ziemlich gewölbt, wie der Kopf punktirt und behaart. Die Flügeldecken sind nicht ganz um die Hälfte länger als das Halsschild, oben dicht und stark runzelig punktirt, etwas länger und weniger fein als der übrige Körper behaart. Der Hinterleib ist vor der Spitze nicht schmäler als die Flügeldecken, nach der Basis zu nur wenig verengt, oben mälsig dicht und fein punktirt. Die Beine sind blafsgelb.

Ein einziges 오. 
Sunius longicollis n. sp.

Elongatus, testaceus, capite thoraceque rufis, antennis elongatis pedibusque pallide flavis; capite elytris latiore oblongo thoraceque oblongo-obovato dense subtiliter reticulato-punctatis; elytris thorace parum longioribus sat crebre minus fortiter, abdomine densius subtiliter punctatis. - Long. $1 \frac{2}{3}$ lin.

Mas: Abdominis segmento inferiore $7^{0}$ apice medio latius emarginato.

Von gestreckter Gestalt, Kopf und Halsschild röthlich, der übrige Körper gelblich, die Fühler und Beine blafsgelb. Der Kopf ist etwas breiter als die Flügeldecken, länglich, an den Seiten hinter den Augen und am Hinterrande in gemeinschaftlichem Bogen gerundet, oben in der Mitte gewölbt, nach hinten etwas abgeflacht, zwischen den Augen leicht quer eingedrückt, vor denselben flach, äufserst dicht und fein netzförmig punktirt, fein und kurz anliegend behaart, kaum glänzend. Auf der Unterseite ist der Kopf hinten zerstreut, in der Mitte ziemlich dicht und kräftig, gegen den Mund hin feiner netzförmig punktirt. Die schlanken fadenförmigen Fühler sind kaum kürzer als Kopf und Halsschild, auch die vorletzten Glieder noch um die Hälfte länger als breit. Das Halsschild ist länglich verkehrt eiförmig, gut um ein Drittel länger als breit, an den Seiten vor der Mitte gerundet erweitert, nach vorn in einwärts geschwungener Linie verengt, nach hinten in sanftem Bogen verschmälert, oben wenig gewölbt, an den Seiten in der Mitte seicht schräg eingedrückt, wie der Kopf punktirt und behaart. Die Flügeldecken sind mehr als doppelt so breit als der Hinterrand des Halsschildes, kaum um ein Drittel länger als dasselbe, mälsig dicht und stark punktirt, fein anliegend behaart. Der Hinterleib ist ziemlich dicht und fein, nach hinten $z u$ allmählich immer feiner punktirt. Die Beine sind blafsgelb.

Beim $\widetilde{c}$ ist das 7 te untere Hinterleibssegment hinten in der Mitte breit ausgerandet.

Ein Pärchen.

\section{Sunius pictus n. sp.}

Elongatus, subconvexus, niger, elytrorum apice anoque testaceis, thorace obscure fusco, pedibus pallide flavis geniculis tibiisque nigropiceis, antennis elongatis gracillimis piceis apice albidis; capite suborbiculato elytris parum latiore thoraceque oblongo-obovato lateribus ante medium angulato subtiliter reticulato-punctatis et longitudinaliter strigosulis; elytris thorace vix longioribus crebre 
fortiter, abdomine anterius fortius, apice subtilius minus crebre punctatis. - Long. $1 \frac{2}{3}$ lin.

Mas: Latet.

Eine durch ihre Färbung sehr charakteristische Art, von gestreckter weniger flach gedrückter Gestalt als die vorhergehenden Arten, schwarz, die Flügeldecken an der Spitze und der After gelblich, das Halsschild mattbraun, die Fühler pechbraun, ihre 5 letzten Glieder weifslich gelb, die Beine sammt den Hüften blafsgelb, die Knieen und Schienen pechfarbig. Der Kopf ist etwas breiter als das Halsschild, wenig länger als breit, hinter den Augen an den Seiten und dem Hinterrande in gemeinschaftlichem Bogen gerundet, oben in der Mitte der Quere nach gewölbt, nach vorn abgeflacht, dicht und fein netzförmig punktirt und der Länge nach gestrichelt, kaum glänzend. Die dünnen fadenförmigen Glieder sind länger als Kopf und Halsschild, ihr 3 tes Glied mehr als doppelt so lang als das 2 te, die folgenden alle wohl $3 \mathrm{mal}$ so lang als an der Spitze breit, die 6 ersten Glieder pechbraun, die 5 letzten weifslichgelb. Die Taster sind hell pechfarben, an der Spitze hellgelb. Das Halsschild ist länglich verkehrt-eiförmig, um ein Drittel länger als breit und um ein Drittel schmäler als die Flügeldecken, an den Seiten vor der Mitte winkelig erweitert, von da plötzlich in einwärts geschwungener Linie nach vorn verengt, nach hinten allmählich verschmälert, hinter der Mitte seicht ausgerandet, oben wenig gewölbt, fast noch dichter als der Kopf längsgestrichelt und gerunzelt, ganz matt. Die Flügeldecken sind mehr als doppelt so breit als der Hinterrand des Halsschildes, wenig länger als dasselbe, oben gewölbt, vorn längs der Naht ziemlich breit und tief eingedrückt, dicht, kräftig und tief punktirt. Der Hinterleib ist vor der Spitze so breit als die Flügeldecken, nach vorn schwach verengt, auf den vorderen Segmenten ziemlich kräftig und nicht dicht, auf den beiden letzten dichter und feiner punktirt. Die Kniee und Schienen der hellgelben Beine sind pechbraun, die hintersten Schienen in der hintern Hälfte wieder hellgelb wie sämmtliche Tarsen.

Ein einziges ㅇ.

Scopaeus major n. sp.

Elongatus, subconvexus, omnium creberrime subtilissimeque punctalus et pube tenuissima grisea obductus, sericans, subnitidus, piceus capite nigro, elytris dimidio posteriore antennisque rufis, abdomine rufo-fusco segmentorum marginibus apiceque dilutioribus, 
pedibus testaceis; capite subquadrato, thorace oblongo, aequali, apice attenuato, elytris hoc longioribus. - Long. $1 \frac{2}{3}$ lin.

Mas: Abdominis segmento inferiore $6^{0}$ apice late leviter emarginato, $7^{0}$ late profundeque subtriangulariter exciso.

Eine der gröfseren Arten der Gattung, von gestreckter Gestalt, ziemlich gewölbt, äufserst dicht und fein punktirt und mit äufserst dichter, zarter und kurzer seidenglänzender Behaarung überzogen, daher nur wenig glänzend, pechbraun, der Kopf schwarz oder pechschwarz, die Flügeldecken in ibrer hinteren Hälfte ohne scharfe Abgrenzung röthlich, der Hinterleib hellbraunroth mit röthlichem Hinterrand der Segmente und röthlichem After, die Fühler roth, die Beine rothgelb. Der Kopf ist quadratisch, an den Seiten zum Hinterrande gerade verlaufend, hinten fast gerade abgestutzt, an den Hinterecken kurz zugerundet, der Scheitel mit einer feinen kurzen Längsrinne. Die rothe Lefze ist hoch, an der Spitze mit 4 scharfen Zähnen bewaffnet, von denen die mittleren durch einen tiefen dreieckigen Ausschnitt von einander getrennt sind, während die äufseren fast in gleicher Höhe mit den mittleren liegenden nur durch eine kurze, hinten abgerundete Ausbuchtung von der letzteren geschieden sind. Die Fühler sind roth, gleich dick, kürzer als Kopf und Halsschild, das 3 te Glied um die Hälfte länger und etwas schmäler als das 2 te, von den folgenden die ersteren etwas länger als breit, die letzten noch so breit als lang, das Endglied kurz eiförmig zugespitzt. Das Halsschild ist etwas schmäler als der Kopf und um gut ein Drittel schmäler als die Flügeldecken, um gut ein Drittel länger als breit, an den Seiten schwach gerundet, binten etwas eingezogen, vorn vor der Mitte plötzlich in einwärts geschwungener Linie rerengt, hinten gerade abgeschnitten, ohne deutliche Längslinie in der Mitte und ohne deutliche Basalgrübchen. Die Flügeldecken sind um die Hälfte länger als das Halsschild, in ihrer hintern Hälfte röthlichgelb. Der Hinterleib ist fast gleichbreit, vor der Spitze nur unmerklich erweitert. Die Beine sind gelblichroth.

Beim $\sigma^{\tau}$ ist das 6te untere Hinterleibssegment hinten der ganzen Breite nach seicht ausgerandet, das 7 te in der Mitte breit und tief dreieckig ausgeschnitten, die Spitze des Dreiecks abgerundet.

In geringer Anzahl gefunden.

Scopaeus fossiceps n. sp.

Elongatus, linearis, subdepressus, pube subtili flavescente confertissime obductus, opacus, rufus, capile elytrisque nigro-piceis, 
antennis rufo-fuscis, pedibus rufo-testaceis; capite subquadrato medio canalicula tenui longitudinali exarato, thorace oblongo apice attenuato aequali, elytris hoc longioribus. - Long. $1 \frac{1}{2}$ lin.

Mas: Abdominis segmento ventrali $7^{0}$ medio apice breviter triangulariter exciso.

Von gestreckter, gleichbreiter, etwas flachgedrückter Gestalt, von nicht allzu feiner graugelber Behaarung so dicht überzogen, dafs eine Skulptur unter derselben nicht wahrzunehmen ist, ganz matt, roth mit pechschwarzem Kopfe und ebenso gefärbten Flügeldecken, braunrothen Fühlern und rothgelben Beinen. Der Kopf ist quadratisch, fast etwas breiter als die Flügeldecken, an den Seiten gerade, am Hinterrande breit aber seicht ausgebuchtet, an den Hinterecken kurz abgerundet, in der Mitte von einer feinen vorn und hinten abgekürzten Längsrinne durchzogen. Die Lefze ist braunroth, ihre mittleren Zähne grofs und scharf, die seitlichen undeutlich. Die Taster sind rothbraun. Die gleichbreiten Fühler sind braunroth, ziemlich dick, kürzer als Kopf und Halsschild, das 3 te Glied etwas dünner aber nicht kürzer als das 2te, das 4 te und 5 te wenig länger als breit, die folgenden von gleicher Gröfse, fast so lang als breit, das Endglied eiförmig zugespitzt. Das Halsschild ist um gut ein Drittel länger als breit und um ein Drittel schmäler als der Kopf, an den Seiten gerade, nach hinten kaum verschmälert, am Hinterrande gerade abgeschnitten, an den Hinterecken abgerundet, an den Seiten vor der Mitte plötzlich und stark nach vorn verengt, oben ohne Längslinie und ohne Basalgruben. Die gleichbreiten Flügeldecken sind um ein Drittel länger und breiter als das Halsschild. Der Hinterleib ist vor der Spitze erweitert, einfarbig roth. Die Beine sind rothgelb.

Beim $\widetilde{c}$ ist der Hinterrand des 7 ten unteren Hinterleibssegments kurz dreieckig ausgeschieden.

Zahlreicher als die vorige Art aufgefunden.

\section{Scopaeus pruinosulus n. sp.}

Elongatus, linearis, pube brevissima tenuissima confertissime pruinosulus, parum nitidus, rufo-testaceus, capite thoraceque rufis; capite subquadrato, thorace elongato apice attenuato, elytris hoc longioribus. - Long. $1 \frac{1}{3}$ lin.

Mas: Abdominis segmento $6^{0}$ ventrali apice late leviter emarginato, $7^{\circ}$ profunde rotundatim exciso.

In der Gestalt und in dem Verhältnifs der einzelnen Körpertheile zu einander der vorigen Art täuschend ähnlich, aber nur 
halb so grofs, heller gefärbt, ohne Kopfrinne und mit ganz anderer Geschlechtsauszeichnung des $\sigma^{\uparrow}$, - einfarbig gelblichroth mit rothem Kopf und Halsschild, mit äufserst kurzer, feiner, grauer, dichter, reifartiger Behaarung bekleidet, wenig glänzend, ohne deutliche Punktirung. Der Kopf ist etwas länger als bei der vorhergehenden Art, im Uebrigen von gleicher Bildung, ohne Längsrinne in der Mitte, aber mit feinem, schmalem Scheitelgrübchen. Die Fühler sind kräftig, fast so lang als Kopf und Halsschild, das Verhältnifs der einzelnen Glieder ganz wie bei Sc. fossiceps. Ebenso ist in der Form des Halsschildes kaum ein Unterschied von der vorhergehenden Art zu erkennen, nur dafs in der vordern Hälfte derselben zuweilen eine äufserst feine, glatte, leicht erhabene Längslinie bemerkbar ist. Die Flügeldecken und der Hinterleib sind wie bei Sc. fossiceps.

Die Geschlechtsunterschiede des $\sigma^{\Uparrow}$ sind ganz ähnlich wie bei Sc. major ausgebildet, das 6te Bauchsegment ist hinten der ganzen Breite nach seicht ausgerandet, das 7 te in der Mitte tief hufeisenähnlich ausgeschnitten.

In ziemlicher Anzahl erhalten.

Scopaeus tenuis n. $\mathrm{sp}$.

Elongatus, subdepressus, subtilissime pubescens, subnitidus, piceus, elytris apicem versus dilutioribus, thorace anoque rufis, antennis pedibusque testaceis; capite thorace perparum latiore subquadrato, elytris thorace oblongo longioribus. - Long. $\frac{3}{4}$ lin.

Mas: Abdominis segmento $6^{0}$ medio late minus profunde impresso, apice medio emarginato, $7^{0}$ medio utrinque longitudinaliter suboblique impresso, inter impressiones elevato-subplicato, apice ipso tenuiter subtriangulariter exciso.

$\mathrm{Zu}$ den kleinsten Artèn der Gattung gehörend, von schmaler, gestreckter, flachgedrückter Gestalt, äufserst fein behaart, mäfsig glänzend, ohne deutliche Punktirung der Oberfläche. Der Körper ist pechbraun, die Flügeldecken gegen die Spitze hin etwas lichter, das Halsschild und die Hinterleibsspitze roth, die Fühler und Beine rothgelb. Der Kopf ist quadratisch, etwas breiter als das Halsschild, an den Seiten fast gerade, am Hinterrand schwach ausgebuchtet, an den Hinterecken abgerundet. Die Fühler sind etwas länger als der Kopf, nach der Spitze zu deutlich verdickt, das 3 te Glied so lang aber etwas schmäler als das 2te, das 4 te wenig kürzer als das 3te, die folgenden allmählig etwas breiter werdend, die ersten fast noch länger als breit, die vorletzten leicht trans- 
versal, das Endglied kurz eiförmig. Das Halssehild ist um ein Drittel schmäler als die Flügeldecken, nicht ganz um die Hälfte länger als breit, an den Seiten fast gerade, vorn vor der Mitte nach der Spitze zu stark verengt, nach hinten ganz unmerklich verschmälert, mit stumpf abgerundeten Vorder- und Hinterecken, oben in der Mitte mit einer vorn schwachen, hinten deutlicher hervortretenden leicht erhabenen Längslinie, zu deren Seiten an der Basis sich je ein kleines schwaches, oft kaum sichtbares Grübchen befindet. Die Flügeldecken sind gut um ein Drittel länger als das Halsschild, der Hinterleib vor der Spitze erweitert, gegen die Basis hin allmählig verschmälert. Die Beine sind hell gelbroth.

Beim $\sigma^{\pi}$ ist das 6 te untere Hinterleibssegment in der Mitte der ganzen Länge nach breit aber seicht eingedrückt, hinten in der Mitte schwach ausgerandet; das 7 te Segment hat in der Mitte zwei schräg verlaufende, nach hinten convergirende Längseindrücke, zwischen denen es fältchenartig erhaben ist; das Ende des Fältchens verliert sich am Hinterrande in einen kleinen dreieckigen Ausschnitt, dessen Ränder schwach gewulstet erscheinen.

Nur wenige Exemplare.

\section{Scopaeus laetus n. sp.}

Subconvexus, nitidus, rufus, elytris nigris sutura apiceque rufotestaceis, abdomine obscure fusco, opaco, pedibus testaceis; capite rotundato-quadrato, thorace latiore, hoc subovato apice attenuato basi foveola gemina impresso, elytris thorace longioribus. - Long. 1 lin.

Mas: Abdominis segmentis $3^{0}-6^{0}$ medio fovea rotundata anum versus paullatim minore obsoletioreque impressis, $6^{0}$ apice late levius subtriangulariter emarginato, $7^{0}$ late rotundatim exciso.

Von der Gestalt des Sc. laevigatus, aber viel kleiner und anders gefärbt, etwas gewölbt, auf dem Vorderkörper fein, dünn und hinfällig behaart, daher lebhaft glänzend, auf dem Hinterleib äufserst dicht behaart, matt, obne deutliche Punktirung der Oberfläche. Die Farbe ist ein lebhaftes Roth, welches auf dem Kopf zumeist ein wenig dunkler ist als auf dem Halsschild, die Flügeldecken sind schwarz, an der Naht schmäler, an der Spitze breiter rothgelb gesäumt, der Hinterleib dunkelbraun, der After und zuweilen auch der schmale Hinterrand der Segmente rothbraun, die Fühler röthlich, an der Spitze heller, die Beine gelblich. Der Kopf ist etwas breiter als das Halsschild, wenig breiter als lang, fast 
quadratisch, aber an den Hinterecken breit abgerundet, am Hinterrande kaum seicht ausgeschnitten. Die Fühler sind kürzer als Kopf und Halsschild, das 2 te Glied etwas länger und dicker als das 3 te, dieses und das 4 te fast gleich grofs, die folgenden an Stärke wenig verschieden, die ersten kaum länger als breit, die vorletzten kaum breiter als lang, das Endglied eiförmig. Das Halsschild ist fast eiförmig, um ein Drittel schmäler als die Flügeldecken und um ein Drittel länger als breit, hinten leicht gerundet, vorn verengt, an den Seiten mit den Vorderecken sanft gerundet, oben gewölbt, an der Basis mit 2 tiefen länglichen Grübchen, welche durch eine schmale kielförmig erhabene, plötzlich erlöschende Längslinie von einander getrennt sind. Die Flügeldecken sind um ein Drittel länger als das Halsschild. Der Hinterleib ist fast gleichbreit, vor der Spitze äufserst wenig verbreitert.

Beim $\sigma^{\pi}$ hat das 3 te bis 6 te Segment auf der Unterseite in der Mitte ein rundliches Grübchen, welches je näher der Spitze des Hinterleibs desto kleiner und oberflächlicher wird, auf dem 3 ten Ringe also am stärksten und tiefsten, auf dem 6 ten am kleinsten und seichtesten ist; der Hinterrand des 6ten Segments ist der ganzen Breite nach seicht dreieckig ausgerandet, der des 7 ten Ringes der ganzen Breite nach bogenförmig ausgeschnitten.

In geringer Zahl gefunden. Auch am Cap Verde zu Hause.

\section{Lithocharis peregrina n. sp.}

Elongata, subdepressa, dilute fusca, capite nigro, thorace rufo.fusco, antennis pedibusque ferrugineis; capite orbiculato-subovato fere impunctato, nitido, thorace oblongo-quadrato omnium subtilissime indistincte, elytris hoc longioribus confertissime subtiliter, abdomine apicem versus attenuato basi crebrius apice parce minus subtiliter punctatis. - Long. 2 lin.

Mas: Abdominis segmento $7^{0}$ ventrali apice semicirculariter exciso, tarsis unticis simplicibus.

Von der gestreckten Gestalt der L. obsoleta, wenig gewölbt, bräunlich, das Halsschild mehr röthlich, der Kopf schwarz, der Hinterleib in der Mitte etwas dunkler als an den beiden Enden, die Fühler und Beine rostroth. Der Kopf ist glänzend, wenig schmäler als das Halsschild, etwas länger als breit, am Hinterrande und den Hinterecken sanft gerundet, vor den Augen nach vorn verengt, oben nur in der Mitte etwas gewölbt, auf der Stirn in grofser Ausdehnung glatt, nur an den Seiten und dem Hinterrande 
mit ziemlich dicht stehenden feinen Punkten besetzt, unter welche sich vereinzelte grölsere mischen; einige gröfsere steben auch vorn auf der Stirn oberhalb der Augen. Auf den punktirten Stellen ist der Kopf mälsig dicht graugelb behaart und aufserdem sparsam mit längeren abstehenden Haaren besetzt. Der Mund und die Taster sind röthlich, an den Kiefertastern das 3 te Glied etwas weniger verdickt und das 4te mit etwas breiterer Basis aufsitzend, als dies sonst in der Gattung der Fall zu sein pflegt. Die fadenförmigen Fühler sind kräftig, länger als Kopf und Halsschild, das 3te Glied um mehr als die Hälfte länger als breit, die folgenden an Länge wenig verschieden, die vorletzten nur wenig kürzer aber nicht breiter als die vorhergehenden, noch entschieden länger als breit, das Endglied kaum länger als das 10 te, scharf zugespitzt. Das Halsschild ist um ein Drittel schmäler als die Flügeldecken und um ein Drittel etwa länger als breit, an allen Ecken kurz abgerundet, vorn gerade abgeschnitten, hinten in der Mitte deutlich ausgerandet, an den Seiten fast gerade, nach hinten unmerklich verengt, oben glänzend, dicht aber äufserst fein, undeutlich und unbestimmt punktirt, dicht und fein anliegend gelblich behaart, an den Seiten mit einigen längeren Haaren besetzt, in der Mitte zuweilen mit einer Spur einer eingedrückten Längslinie. Die Flügeldecken sind um ein Drittel länger als das Halsschild, äufserst dicht, fein punktirt und behaart, matt, die Behaarung etwas länger und weniger fein als auf dem Halsschild. Der glänzende Hinterleib ist nach der Spitze ziemlich stark verengt, oben nur mälsig dicht und fein, länger und gröber als die Flügeldecken behaart, an den Seiten nach hinten zu und an der Spitze mit längeren Haaren nicht gerade sparsam besetzt, vorn mäfsig dicht, nicht fein, etwas ungleich, reibeisenartig, hinten allmählig viel sparsamer punktirt. Die Beine sind röthlich, lang und schlank, die Vorderschienen wie in der Gattung Scimbalium in beiden Geschlechtern innen in der Mitte ausgebuchtet, am hintern Ende der Ausbuchtung stumpf gezahnt, die Vordertarsen in beiden Geschlechtern einfach.

Beim $\widehat{\sigma}$ ist der Hinterrand des 7 ten untern Hinterleibssegments breit halbkreisförmig ausgeschnitten, hinter der Ausrandung mit einer dreieckigen spiegelglatten Stelle versehen.

Eine gröfsere Reihe von Exemplaren.

\section{Lithocharis nitidiventris $\mathrm{n}$. $\mathrm{sp}$.}

Elongata, subdepressa, densius minus subtiliter pubescens, obscure fusca, opaca, capite nigro abdomineque rufo-fusco medio obscuriore 
nitidis, hoc segmentorum marginibus anoque, antennis pedibusque rufo-testaceis; capite subquadrato thoracis latitudine thoraceque oblongo-quadrato laevibus, elytris hoc longioribus creberrime subtiliter punctatis, abdomine apicem versus attenuato supra parce fortiter scabroso-punctato. - Long. $1 \frac{1}{2}$ lin.

Mas: Abdominis segmento $7^{0}$ ventrali apice late subrotundatim emarginato.

Ganz von der Gestalt der vorhergehenden Art, aber nur halb so grofs und in vielen Punkten abweichend. Der Körper ist gestreckt, nach hinten stark verschmälert, oben wenig gewölbt, ziemlich dicht, wenig fein behaart, Halsschild und Flügeldecken matt, der Kopf und der Hinterleib glänzend; Halsschild und Flügeldecken sind schmutzig dunkelbraun, das erstere im hintern Drittheil heller rothbraun, der Kopf schwarz, der Hinterleib braun mit einem Stich ins Röthliche, das 5te Segment schwarz, der Seiten- und Hinterrand der einzelnen Segmente, die hintere Hälfte des 6ten und der ganze 7 te Ring heller roth, die Fühler und Beine rothgelb. Der Kopf ist so breit als das Halsschild, etwas breiter als lang, querquadratisch, an den Seiten fast gerade, an den Hinterecken kurz abgerundet, oben glänzend, glatt, unpunktirt, nur an den Seiten mit wenigen undeutlichen Punkten versehen, mit dichter stehenden, halb anliegenden kürzeren und sparsamen abstehenden längeren Haaren besetzt. Der Mund und die Taster sind röthlich. Die Fühler sind kräftig, länger als Kopf und Halsschild, roth, an der Basis und Spitze heller gelb, das erste Glied sehr lang und stark, die beiden folgenden nur mäfsig gestreckt, das 3te nur wenig länger als das 2te, von den folgenden die ersten entschieden länger als breit, die vorletzten noch so lang als breit, das Endglied etwas länger als das 10te, vorn kurz zugespitzt. Das Halsschild ist ganz und gar wie bei der vorigen Art gebildet, kaum um ein Drittel schmäler als die Flügeldecken, gut um ein Drittel länger als breit, oben matt, unpunktirt, ohne sichtbare Mittellinie, wie der Kopf behaart. Die Flügeldecken sind kaum um ein Drittel länger als das Halsschild, oben flach, äufserst dicht, fein punktirt, kaum feiner als dieses behaart. Der Hinterleib ist vorn schmäler als die Flügeldecken, nach hinten stark verengt, oben sparsam, grob und raub, reibeisenartig punktirt, weniger dicht als die Flügeldecken behaart, hinten an den Seiten und an der Spitze mit längeren abstehenden Haaren besetzt. Beim $\widetilde{\tau}$ ist der Hinterrand des 7 ten Ventralsegments rundlich ausgerandet, die Vordertarsen einfach.

In geringer Zahl erhalten. 


\section{Medon Simoni n. sp.}

Minus elongatus, subconvexus, subtiliter pubescens, nitidus, obscure rufus, elytris anoque brunneo-testaceis, antennis pedibusque testaceis, abdomine rufo-fusco; capite transversim quadrato thorace sublatiore, hoc transverso, basin versus angustato, medio posterius carinulato, elytris thorace dimidio longioribus, abdomine subparallelo; capite thoraceque confertim fortius, elytris subtilius, abdomine subtilissime punctatis. - Long. 1 lin.

Mas: Abdominis segmento $7^{0}$ ventrali apice semicirculariter exciso.

In der Gestalt dem $\boldsymbol{M}$. debilicornis am ähnlichsten, noch etwas kürzer und gedrungener, namentlich das Halsschild kürzer und breiter, dunkler gefärbt und ganz anders punktirt. Die Farbe ist ein gesättigtes braunroth, die Flügeldecken und die Hinterleibsspitze sind heller bräunlichgelb, die Fühler und Beine rothgelb; die Oberfläche des Körpers ist mälsig gewölbt, glänzend, fein, nicht sehr dicht behaart. Der Kopf ist querquadratisch, fast breiter als das Halsschild, hinten breit, aber seicht ausgerandet, in der Mitte des Hinterrands mit einem tief dreieckig eingedrückten Scheitelgrübchen, an den Seiten gerade verlaufend mit kurz abgerundeten, fast rechtwinkeligen Hinterecken, oben dicht und kräftig punktirt, in der Mitte mit einer äufserst feinen, kaum sichtbaren glatten Längslinie. Die Fühler sind viel kürzer als Kopf und Halsschild, kräftig, nach der Spitze zu verdickt, das 2 te Glied nur wenig länger aber um die Hälfte dicker als das 3te, wenig länger als breit, das 3te und 4te kaum länger als breit, fast quadratisch, das 5 te und 6 te rundlich, kaum breiter als das 4te, die nachfolgenden rasch an Breite zunehmend, die beiden vorletzten doppelt so breit als lang, das Endglied kurz eiförmig, vor der Spitze schräg ausgerandet. Das Halsschild ist etwas schmäler als die Flügeldecken, nicht ganz doppelt so breit als lang, fast hexagonal, an den Seiten geradlinig und allmählig nach hinten leicht verschmälert, nach vorn plötzlich in einwärts geschwungener Linie stark verengt, am Hinterrande sanft abgerundet, mit stumpfen Hinter- und Vorderecken, oben quer gewölbt, wie der Kopf punktirt, in der Mitte von einer feinen leicht erhabenen glatten Längslinie durchzogen, welche weder den Vorder-noch den Hinterrand erreicht. Die Flügeldecken sind um die Hälfte länger als das Halsschild, weniger gewölbt als dieses, oben eben so dicht und kaum feiner als dieses, aber etwas oberflächlicher punktirt, mit einem über die Hälfte der Länge reichenden ziemlich tiefen Längseindruck zu beiden Seiten der Naht. Der Hinterleib ist gleichbreit, 
ziemlich dicht, an der Basis der einzelnen Segmente äufserst dicht fein punktirt. Die Beine sind gelblich.

Beim $\sigma^{\top}$ ist das 7 te Ventralsegment am Hinterrande halbkreisförmig ausgeschnitten.

Etwas zahlreicher als die vorige Art gesammelt. Meinem lieben Freunde Hans Simon als Zeichen meiner Dankbarkeit freundschaftlichst gewidmet.

\section{Medon intermixtus n. sp.}

Minus elongatus, subconvexus, dense minus subtiliter pubescens, obscurius fusco-rufus, subopacus, elytris nitidis brunneo-testaceis, abdomine fusco, ano, antennis pedibusque testaceis; capite transversim quadrato thorace sublatiore, hoc transversim hexagonali posterius subcarinato basi 4-punctato, elytris thorace sesqui longioribus; capite thoraceque confertissime illo fortius hoc subtiliter, elytris crebre minus subtiliter punctatis, punctis majoribus subseriatim positis intermixtis; abdomine parallelo subtilissime punctato. - Long. $1 \frac{1}{3}$ lin.

Mas: Latet.

Der vorigen Art täuschend ähnlich und in der Gesammtform des Körpers sowohl wie im Verhältnifs der einzelnen Theile zu einander vollkommen mit derselben übereinstimmend, aber doppelt so grofs, dunkler gefärbt, durch andere Skulptur des Vorderkörpers vornehmlich abweichend. Der Kopf ist querquadratisch, ein klein wenig breiter als das Halsschild, hinten sehr seicht ausgerandet, an den Hinterecken kurz abgerundet, oben äufserst dicht, ziemlich kräftig, runzelig punktirt und dicht, nicht gerade fein behaart, matt, ohne Scheitelgrube. Die Fühler sind ganz und gar wie bei der vorhergehenden Art gebildet. Ebenso ist in der Form des Halsschildes durchaus kein Unterschied von M. Simoni vorhanden, aber die Oberfläche ist viel dichter und feiner runzelig punktirt und viel dichter behaart, daher matt, die Längslinie in der Mitte ist gegen den Hinterrand zu deutlicher erhaben hervortretend und vor dem letzteren finden sich in der Mitte 4 gleichweit von einander abstehende, quer gestellte Punkte, ron denen die beiden mittleren stärker und tiefer sind als die äufseren. Die Flügeldecken sind um die Hälfte länger als das Halsschild, oben etwas tiefer und bestimmter punktirt als bei der vorigen Art und zwischen die gewöhnlichen Punkte sind gröbere, stärkere eingestreut, welche in 3-4 unregelmäfsige Längsreihen gestellt sind. Der Hinterleib ist wie bei $M$. Simoni geformt und punktirt.

Zwei ㅇ․ Das $\sigma^{\star}$ ist mir noch unbekannt. 
Die eben beschriebene Art unterscheidet sich von der vorhergehenden durch bedeutendere Gröfse, durch viel dichter punktirten matten Kopf und Halsschild, durch den Mangel des dreieckigen Scheitelgrübchens, durch die 4 Basalpunkte des Halsschildes und durch die eingemischten gröberen reihenweise gestellten Punkte der Flügeldecken. Der Lithocharis biseriata Er. scheint diese Art gleichfalls sehr nahe verwandt zu sein.

Paederus sabaeus Er. (aestuans Boh.). Ein Stück.

Paederus capensis Er. Ein Stück.

Pinophilus brachycerus n. sp.

Linearis, subconvexus, griseo-pubescens, nitidulus, niger, abdominis segmentorum marginibus pedibusque rufo-brunneis, antennis brevibus testaceis; capite crebre fortiter substrigoso-punctato fronte media laevi, thorace subquadrato linea media angusta posterius latiore laevi elytrisque hoc longioribus dense fortiter profundeque rugose punctatis, abdomine crebrius minus subtiliter punctato. - Long. $3 \frac{1}{2}$ lin.

\section{Mas: Latet.}

Von gestreckter gleichbreiter Gestalt, oben wenig gewölbt, mäfsig dicht und fein graugelb behaart, ziemlich glänzend, schwarz, der Hinterrand der einzelnen Abdominalsegmente und die Beine rothbraun, die Taster und Fühler gelblich. Der Kopf ist etwas schmäler als das Halsschild, oben dicht, grob und tief punktirt, in der Mitte schmäler, nach vorn hin breiter glatt, am Vorderrande selbst wieder punktirt, die Punkte zumeist länglich mit längsgerunzelten Zwischenräumen. Die Mandibeln sind rothbraun, die Taster hellgelb. Die Fühler sind hell röthlichgelb, um die Hälfte länger als der Kopf, das 2te Glied nur wenig länger aber viel dicker als das 3te, von den folgenden die ersten etwas länger als breit, die vorletzten so lang als breit. Das Halsschild ist fast quadratisch, nur wenig breiter als lang, an den Seiten gerade, nach hinten kaum verschmälert, vorn gerade abgeschnitten, am Hinterrande sanft gerundet, mit niedergedrückten kurz gerundeten Vorderund stumpf zugerundeten Hinterecken, oben der Quere nach gewölbt, dicht, grob und tief punktirt, in der Mitte mit einer schmalen hinten breiteren und schwach erhabenen glatten Längslinie. Die Flügeldecken sind um ein Drittel länger als das Halsschild, neben der Naht der ganzen Länge nach beiderseits eingedrückt, oben dicht, fast noch gröber und tiefer als das Halsschild punktirt. Der Hinterleib ist nur wenig schmäler als die Flügeldecken, oben nur 
mälsig dicht und fein punktirt, Die Beine sammt den Hüften sind rothbraun, die vordersten Beine sehr kurz und breit, ihre Schenkel stark verdickt, auch ihre Schienen erweitert, ihre Tarsen kaum mehr als um die Hälfte breiter als das Schienenende.

Das $\sigma^{\pi}$ ist mir unbekannt.

Ein einziges ㅇ.

Pinophilus reticulatus Fauv. i. 1.

Linearis, deplanatus, parum nitidus, griseo-pubescens, dilute castaneus, antennis gracillimis pedibusque rufo-testaceis; capite thorace paullo angustiore, hoc subquadrato basin versus subangustato linea tenuissima media laevi, elytris thorace longioribus; capite nitido sparsim, thorace elytrisque dense illo subtiliter his fortius subrugose, abdomine crebrius reticulato-punctatis. - Long. $3 \frac{1}{3}$ lin.

Mas: Abdominis segmentis ventralibus $3^{0}-6^{0}$ medio longitudinaliter angustius, $7^{0}$ late profundeque impressis, impressionis lateribus plicato-elevatis.

Von der flachgedrückten Gestalt des $P$. complanatus, ziemlich gleichbreit, wenig glänzend, hell kastanieubraun mit rothgelben Fühlern und Beinen. Der Kopf ist glänzend, etwas schmäler als das Halsschild, oben mit ganz vereinzelten, ziemlich kräftigen Punkten und aus diesen Punkten entspringenden abstehenden schwarzen Haaren besetzt, in der Mitte ganz glatt. Die Fühler sind äufserst schlank und dünn, länger als Kopf und Halsschild, das 2te Glied kaum kürzer aber doppelt so dick als das 3te, das 4te etwas länger als das 3te, die folgenden allmählig an Länge abnehmend, die vorletzten noch mehr als doppelt so lang als breit, das Endglied scharf zugespitzt. Das Halsschild ist etwas schmäler als die Flügeldecken, querquadratisch, kaum um ein Drittel breiter als lang, vorn und hinten ziemlich gerade, an den Seiten unmerklich gerundet und nach hinten sanft verengt, mit stumpf abgerundeten Vorder- und stumpfwinkeligen Hinterecken, auf der Mitte des Rückens, besonders gegen die Basis zu, breit aber flach eingedrückt, in der Mitte von einer äufserst feinen, hinten leicht erhabenen Längslinie durchzogen, oben dicht und fein punktirt und graugelb behaart, wenig glänzend, gegen die Vorderecken zu etwas weniger dicht punktirt und glänzender. Die Flügeldecken sind kaum um ein Drittel länger als das Halsschild, am Hinterrande gemeinschaftlich bogenförmig ausgerandet, an den Schultern abgerundet, oben flach, längs der Naht beiderseits eingedrückt, eben so dicht als das Halsschild aber viel stärker runzelig punktirt, mäfsig dicht grau- 
gelb behaart. Der Hinterleib ist wenig schmäler als die Flügeldecken, an der Spitze verengt, oben wenig dicht, nur mälsig fein, netzförmig wie in der Gattung Palaminus punktirt. Die Beine sind verhältnifsmäfsig schlank, namentlich die Vorderbeine nicht besonders verdickt, die Vordertarsen wenig breiter als die Schienen.

Beim $\sigma^{\top}$ ist das 3te bis 6te Ventralsegment in der Mitte der Länge nach mit einem auf jedem folgenden Ringe schwächer werdenden Eindrucke versehen, so dafs also der des 3ten Segmentes am tiefsten, der des 6ten am oberfächlichsten ist, das 7 te Segment ist nur an den Seiten sparsam punktirt, in der Mitte glatt, von einer breiten tiefen Längsrinne durchzogen, deren Ränder kielförmig erhaben sind.

Zwei $q$ und ein $\sigma^{\top}$.

\section{Pinophilus infans n. sp.}

Deplanatus, linearis, griseo-pubescens, nitidus, rufus, abdomine fusco-rufo, pedibus rufo-testaceis, antennis pallide flavis; capite thoracis fere latitudine, hoc subquadrato posterius parum angustato linea media latiore subelevala laevi, elytris thorace longioribus; capite sparsim, thorace parce, elytris abdomineque crebre fortius punctatis. - Long. $1 \frac{1}{2}$ lin.

Von der flachgedrückten Gestalt der vorhergehenden Art, dreifach kleiner, heller gefärbt und anders punktirt. Der Körper ist röthlich mit einem leichten Stich ins Braune, der Hinterleib mehr bräunlich, die Beine rothgelb. Die Fühler blafsgelb, die Oberfläche ziemlich sparsam graugelb behaart, glänzend. Der Kopf ist wenig schmäler als das Halsschild, oben in der Mitte, am Vorderrande und in den Hinterecken mit einigen wenigen Punkten und aus diesen Punkten entspringenden abstehenden Haaren besetzt, sonst glatt, glänzend. Die Taster und Fühler sind blafsgelb, letztere kürzer als Kopf und Halsschild, das 2te Glied fast um die Hälfte länger und doppelt so dick als das 3 te, die folgenden Glieder ganz wie bei der vorhergehenden Art gebildet, nur alle verhältnifsmälsig etwas kürzer. Das Halsschild ist fast quadratisch, etwas breiter als lang, so breit als die Flügeldecken, vorn kaum ausgerandet, hinten an den Seiten mit dem Hinterrande in gleichmäfsigem Bogen gerundet, nach hinten etwas rerengt mit breit abgerundeten Hinterund fast stumpfwinkeligen Vorderecken, oben ziemlich sparsam mälsig stark punktirt, an den Vorderecken ganz glatt, sparsam anliegend behaart, in der Mitte von einer breiteren, hinten kielförmig erhabenen glatten Längslinie durchzogen, beiderseits der- 
selben seicht eingedrückt. Die Flügeldecken sind kaum um ein Drittel länger als das Halsschild, hinten beiderseits schräg nach innen abgestutzt, an den Hinterecken abgerundet, die Schultern wenig vorstehend, oben mäfsig dicht, viel dichter aber nicht stärker als das Halsschild punktirt und dichter und etwas gröber behaart. Der Hinterleib ist kaum schwächer und weniger dicht punktirt als die Flügeldecken, die Punkte sind aber etwas rauher, von hinten eingestochen. Die Beine sind verhältnifsmäfsig kürzer und breiter als bei der vorigen Art, namentlich die Vorderbeine kurz und dick, ihre Tarsen fast doppelt so breit als die Schienen. Geschlechtsunterschiede sind mir nicht völlig klar geworden; beim $\sigma^{\uparrow}$ scheint der Hinterrand des 6ten Ventralsegments etwas deutlicher ausgerandet zu sein als beim 오.

Oedichirus terminatus Er. 2 Stück.

Ich schliefse hier die Beschreibung eines neuen Oedichirus vom Cap Verde an, welcher auf dem afrikanischen Festlande weiter verbreitet zu sein scheint, nach Fauvel's brieflicher Mittheilung auch in Abyssinien vorkommt und wohl auch noch an der Goldküste gefunden werden dürfte:

\section{Oedichirus melanurus n. sp.}

Oed. heteropygus Fauv. i.l.

Rufo-testaceus, nitidus, parce pilosus, abdominis segmentis ultimis tribus nigris, elytris thorace longioribus. - Long. 3 lin.

Von der Gröfse und Gestalt des Oed. terminatus, geflügelt, glänzend, sparsam lang gelblich behaart, mit Ausnahme der drei schwarzen letzten Hinterleibssegmente einfarbig rothgelb. Der Kopf ist rundlich, mit den schwarzen Augen fast etwas breiter als das Halsschild, zwischen denselben und vorn mit vereinzelten starken Punkten besetzt, hinter denselben ganz glatt, nur dicht am Hinterrande noch mit wenigen Punkten. Die Taster sind gelblich. Die Fühler sind dünn und schlank, fadenförmig, so lang als Kopf und Halsschild, das 3te Glied fast etwas länger und um die Hälfte dünner als das 2te, die folgenden an Länge allmählig fast unmerklich abnehmend, alle viel länger als breit, die zwei letzten etwas stärker und kürzer als die übrigen, das Endglied lang eiförmig, scharf zugespitzt. Das Halsschild ist um ein Drittel länger als breit, hinten nur halb so breit als die Flügeldecken, vorn an den Seiten erweitert mit breit gerundeten Vorderecken, nach hinten verengt, oben gewölbt, vorn und an den Seiten sparsam grob 
punktirt, in der Mitte von zwei tiefen im Grunde grob punktirten Furchen durchzogen, welche weit hinter dem Vorderrand beginnend bis kurz vor den Hinterrand reichen und einen kielförmig erhabenen Raum einschliefsen. Die Flügeldecken sind etwas länger als das Halsschild, an den Seiten leicht gerundet mit stumpf vorstehenden Schulterecken, hinten gemeinschaftlich bogenförmig ausgerandet, oben ziemlich gewölbt, sparsam mit groben, tiefen, hier und da gereihten Punkten besetzt. Der Hinterleib ist schmäler als die Flügeldecken, cylindrisch, oben etwas dichter und feiner in deutlichen Querreihen punktirt, das 7te Segment mit zwei langen geraden scharf zugespitzten Dornen bewaffnet. Die Beine sind hellgelb.

Ein einziges ․

\section{Edaphus africanus n. sp.}

Latior, posterius parce subtilissime pubescens, nitidus, laevis, rufo-testaceus; capite supra inter oculos linea transversa profundius impressa, antice breviter bisulcato; thorace subcordato, latitudine haud longiore basi 4-foveolato, elytris hoc duplo latioribus et plus duplo longioribus. - Long. $\frac{1}{2}$ lin.

Von den beiden europäischen Arten durch die langen breiten Flügeldecken sehr abweichend, auf Kopf und Halsschild ganz glatt, auf den Flügeldecken und dem Hinterleib sparsam, äufserst fein und hinfällig behaart, glänzend, unpunktirt, rothgelb, auf dem Hinterleib kaum etwas dunkler. Der Kopf ist schmäler als das Halsschild, oben zwischen den Augen mit einer tief eingedrückten Querlinie, oberhalb derselben mit zwei kurzen Furchen, deren Zwischenraum und deren Seitenränder stumpf erhaben sind, so dafs der Vordertheil des Kopfes, von hinten betrachtet, mit drei kleinen Höckern bewaffnet erscheint. Die Taster sind hellgelb. Die Fühler sind röthlich, an der Basis heller, das erste Glied ist etwas dicker aber kaum länger als das 2te, dieses doppelt so lang und so dick als das 3te, das 4te und 5te von gleicher Länge und Form wie das 3te; die fünf ersten Glieder sind cylindrisch, das erste und 2 te doppelt so lang als dick, die drei folgenden wenig länger als breit; das 6 te und 8 te sind kürzer als die vorhergehenden und allmählig sich verbreiternd, knopfförmig, die drei letzten Glieder sind viel stärker als die übrigen und bilden eine deutlich abgesetzte Keule; das erste Glied derselben ist kurz, quer, doppelt so breit als lang und dreimal breiter als das vorhergehende, das 2te Glied der Keule ist fast quadratisch, doppelt so breit und fast dreimal so lang als das erste, das Endglied ist von der Breite des vorber- 
gehenden, eiförmig, stumpf zugespitzt. Das Halsschild ist leicht herzförmig, so breit als lang, vorn und hinten gerade abgeschnitten, an den Seiten vorn gerundet und schwach erweitert, hinter der Mitte schwach ausgerandet und nach hinten verengt, hinten nur wenig schmäler als am Vorderrande, oben gewölbt, vor der Basis quer eingedrückt und mit vier Grübchen, zwei mittleren längeren und zwei seitlichen queren, geziert, von denen die mittleren von einander durch eine längere, die seitlichen von den mittleren durch eine kürzere kielartige Falte geschieden sind. Die Flügeldecken sind an der Basis um die Hälfte breiter als der Hinterrand des Halsschildes, nach hinten schwach bogenförmig erweitert und am Hinterrand doppelt so breit als jener, mehr als doppelt so lang als das Halsschild; an den Schultern sind sie kurz und stumpf abgerundet, neben den Schulterhöckern an der Basis tief und breit eingedrückt, in der Vorderhälfte neben der Naht gemeinschaftlich schwach vertieft, ohne Nahtstreif und ohne erkennbare Punktirung. Der Hinterleib ist vorn so breit als der Hinterrand der Flügeldecken, kurz, nach hinten bogenförmig verengt, an den Seiten vorn hoch und breit, hinten scbwächer gerandet, oben gewölbt, ohne deutlich wahrnehmbare Punktirung. Die Beine sind hellgelb.

Ein einziges Stück.

Fauvel, welchem ich das eben beschriebene Thier unter obigem Namen zur Ansicht schickte, theilte mir brieflich mit, dafs er diese Art unter dem nämlichen Namen aus Abyssinien (Bogos) in seiner Sammlung habe, und war so freundlich, mir ein Exemplar von da abzutreten.

\section{Bledius gemellus n. sp.}

Elongatus, subconvexus, subtiliter pubescens, subtilissime coriaceus, subopacus, niger, elytris nigro-piceis, antennis ano pedibusque rufo-piceis; capite thoracis latitudine, hoc subtransverso medio canaliculato elytrisque thorace latioribus et longioribus confertim subtilius, abdomine parcius fortiusque punctatis. - Long. $2 \frac{1}{2}$ lin.

Mas: Capite supra nitidulo, vertice excavato, fronte lateribus supra antennarum basin acutius angulato-elevatis, thorace apice medio in spinam porrectam canaliculatam producto.

Dem $B l$. tricornis recht ähnlich, etwas kleiner und dunkler gefärbt und auf Halsschild und Flügeldecken viel dichter und feiner punktirt. Der Körper ist etwas weniger gleichbreit als bei $\mathbf{B l}$.tricornis, insofern die Flügeldecken im Verhältnifs zum Halsschild 
breiter sind als bei der verglichenen Art, im Uebrigen von gleicher Gestalt, mäfsig gewölbt, oben überall dicht und fein lederartig gerunzelt, fast matt, auf dem Vorderkörper ziemlich dicht und fein, auf dem Hinterleib sparsamer graugelb behaart - schwarz mit dunkel pechbraunen Flügeldecken, röthlicher Hinterleibsspitze und rothbraunen Fühlern und Beinen. Der Kopf des $q$ ist so breit als das Halsschild, oben leicht gewölbt, beiderseits der Fühlerwurzel stumpfwinkelig aufgeworfen, an den Seiten neben den Augen und hinten mäfsig dicht und fein, seicht punktirt, in der Mitte glatt mit einer feinen Querlinie zwischen den Fühlern und einer eben solchen hinter den Augen, welche beide in der Mitte ein rundliches Grübchen tragen. Die Fühler sind ganz wie bei Bl.tricornis gebildet, braun oder braunroth. Das Halsschild ist nicht ganz um ein Drittel schmäler als die Flügeldecken, um ein Drittel breiter als lang, an den Seiten bis über die Mitte gerade, dann rasch nach hinten verengt mit stumpf abgerundeten Hinterecken, vorn gerade abgeschnitten mit stumpfen Vorderecken, auf dem Rücken gewölbt, dicht und kräftig, aber nicht tief punktirt, mit gerunzelten Zwischenräumen, in der Mitte mit einer hinter dem Vorderrande beginnenden, vorn breiteren Längsrinne. Die Flügeldecken sind um ein Drittel länger als das Halsschild, nach hinten wenig erweitert, dunkel pechbraun, hinten etwas lichter braun, ebenso dicht und kräftig, weniger runzelig wie das Halsschild, viel dichter und etwas feiner als bei $B l$. tricornis punktirt. Der Hinterleib ist oben sparsam, fast noch gröber aber seichter als die Flügeldecken punktirt, an der Spitze röthlich. Die Beine sind rothbraun.

Beim $\widetilde{\sigma}$ ist der Kopf unpunktirt, schwach glänzend, die Stirn vorn seicht der Länge nach, der Scheitel tief quer eingedrückt, die seitlichen Erhabenheiten neben der Einlenkungsstelle der Fühler sind höher und schärfer zugespitzt und der Vorderrand des Halsschildes ist in ein horizontal stehendes gerades, nach der Spitze zu allmählig sich verschmälerndes, vorn zugespitztes rothbraunes Horn ausgezogen, welches oben eine durchgehende Rinne als unmittelbare Fortsetzung der Halsschildrinne trägt.

Diese Art unterscheidet sich von Bl.tricornis durch geringere Grölse, mattere Oberfläche, breitere und dunkler gefärbte Flügeldecken und dichtere Punktirung des Vorderkörpers, das $ð$ aufserdem durch viel niedrigeren schwächeren Stirnhöcker und vorn zugespitztes an der Spitze nicht bebartetes Halsschildhorn.

In geringer Anzahl erhalten. Meine Sammlung besitzt auch ein Exemplar von Cap Verd. 


\section{Bledius nitidicollis n. sp.}

Elongatus, sublinearis, nitidulus, niger, elytris versus angulos posticos, antennis pedibusque testaceis; capite opaco thoracis latitudine, fronte juxta antennarum insertionem leviter elevata, apice denticulis duobus minutis distantibus armata; thorace transverso, posterius rotundato, subtilissime alutaceo, subtiliter punctato, medio canaliculato; elytris hoc longioribus dense subtiliter, abdomine lateribus parce indistincte punctatis. - Long. $1 \frac{1}{2}$ lin.

Mas: Mandibulis supra medium dente obtuso armatis, fronte leviter impressa denticulis apicalibus acutis.

Etwas kleiner als $B l$. verres, auf den Flügeldecken dichter punktirt, durch kürzere einfarbige Fühler und andere Bewaffnung der Stirn unterschieden, ziemlich gestreckt, fast gleichbreit, mälsig gewölbt, fein behaart, glänzend, nur der Kopf matt, schwarz, die Hinterecken der Flügeldecken in gröfserer Ausdehnung, die Fühler und Beine gelblich. Der Kopf ist so breit als das Halsschild, ganz matt, kaum deutlich punktirt, die Stirn beim $q$ flach, beim $\sigma^{\tau}$ breit aber seicht eingedrückt, neben dem Fühleransatz beiderseits mit einem niederen stumpfen, rothgelben, beim $\widetilde{\jmath}$ etwas mehr vortretenden Höckerchen, am Epistom mit zwei winzigen Zähnchen bewaffnet, welche durch einen breiten Ausschnitt von einander geschieden sind. Die Fühler sind einfarbig rothgelb, in beiden Geschlechtern gleichlang, fast so lang als Kopf und Halsschild, das 3te Glied um die Hälfte kürzer als das 2te, das 4te anderthalbmal so lang, das 5te so lang als breit, die folgenden allmählig verbreitert, die fünf letzten eine deutliche Keule bildend.

Die Mandibeln und Taster sind braunroth, die ersten beim 우 unbewaffnet. Das Halsschild ist etwas schmäler als die Flügeldecken, um mehr als ein Drittel breiter als lang, vorn gerade abgeschnitten, hinten an den Seiten mit dem Hinterrande gerundet, vorn an den Seiten bis über die Mitte geradlinig verlaufend mit stumpfen Vorderecken, oben quer gewölbt, äufserst dicht und fein lederartig gerunzelt, so dafs der Glanz der Oberfläche kaum gemindert erscheint und gegen den matten Kopf erheblich absticht, fein und ziemlich dicht punktirt und dünn und hinfällig grau behaart, in der Mitte der ganzen Länge nach von einer feinen Längslinie durchzogen. Die Flügeldecken sind nicht ganz um die Hälfte länger als das Halsschild, nach hinten kaum verbreitert, an den Hinterecken breit abgerundet, am Nahtwinkel klaffend, oben wenig gewölbt, dicht und fein, dichter als das Halsschild punktirt. Der Hinterleib ist sehr wenig schmäler als die Flügeldecken, einfarbig 
schwarz, glänzend, nur an den Seiten sparsam und undeutlich punktirt. Die Beine sind gelblich.

Beim $\widetilde{\sigma}$ ist die Stirn leicht eingedrückt, die Füblerhöcker etwas stärker und die kleinen Zähnchen am Vorderrande der Stirn etwas spitzer als beim $q$; aufserdem sind die Mandibeln oberhalb der Mitte mit einem kurzen stumpfen Zahn bewaffnet.

Von Bl. verres, abgesehen von der Gröfse und Punktirung, durch einfarbig helle, viel kürzere, in beiden Geschlechtern gleichlange Fühler, weit kürzere schwach ausgebildete Fühlerhöcker und durch winzige von einander abstehende, nicht genäherte Zähnchen der Vorderstirne unterschieden.

Wenige Exemplare.

\section{Bledius cavus n. sp.}

Elongatus, sublinearis, subconvexus, parce albido-pubescens, nitidus, capite thoraceque opacis, niger, elytris circa scutellum leviter infuscatis, antennis pedibusque testaceis; capite thorace sublatiore fronte profunde excavata, supra antennarum basin leviter obtuse elevata, apice denticulis duobus distantibus armata; thorace transverso subtiliter alutaceo medio canaliculato parcius, elytris dense subtiliter, abdomine lateribus sparsim indistincte punctatis. - Long. $1 \frac{1}{2}$ lin.

Mas: Fronte profundius excavata, epistomate spinus duabus suberectis subcurvatis munito.

Von der Gröfse und Gestalt der vorhergehenden Art, durch etwas kürzere hellgelbe Flügeldecken, mattes Halsschild und in beiden Geschlechtern tief eingedrückte Stirn vornehmlich unterschieden, ziemlich gleichbreit, mäfsig gewölbt, sparsam, nicht fein weifslich behaart, schwarz, die Flügeldecken hellgelb, in der Schildchengegend leicht gebräunt, die Fühler und Beine gelblich, der Kopf und das Halsschild matt, dicht, nicht allzufein lederartig gerunzelt, der übrige Körper glänzend. Der Kopf ist mit den Augen fast etwas breiter als das Halsschild, die Stirn tief ausgehöhlt, oberhalb der Fühlerwurzel beiderseits mit einem stumpfen rothgelben Höckerchen, hinter dem Vorderrande mit 2 weit von einander abstehenden, gerade unter der Ansatzstelle der Fühler liegeriden Zähnchen bewaffnet. Die Fühler sind einfarbig gelb, etwas kürzer als Kopf und Halsschild, das 2te Glied ist doppelt so lang als das 3te, das 4te etwas kürzer als das 3 te, das 5 te und 6 te noch so lang als breit, die fünf letzten werden allmählig breiter und bilden ein wenig deutlich abgesetzte Keule. Der Mund und die Taster sind hellgelb, 
die Mandibeln rothbraun, in der Mitte in beiden Geschlechtern gezähnt. Das Halsschild ist wenig schmäler als die Flügeldecken, um mehr als die Hälfte breiter als lang, an den Seiten bis zum hintern Drittel sanft verengt, dann plötzlich unter stumpfem Winkel nach hinten eingezogen, vor der Mitte schwach ausgerandet, am Hinterrand sanft gerundet, vorn gerade abgeschnitten mit beinahe rechtwinkeligen Vorderecken, oben gewölbt, dicht lederartig gerunzelt, nur mäfsig dicht und fein punktirt, in der Mitte von einer durchgehenden feinen Längslinie durchzogen. Die Flügeldecken sind kaum um ein Drittel länger als das Halsschild, dicht und fein punktirt. Der Hinterleib ist nur an den Seiten vereinzelt, nicht fein aber seicht punktirt, an der äufsersten Spitze rothgelb. Die Beine sind gelblich. Beim $\sigma^{\star}$ ist die Stirn noch tiefer ausgehöhlt als beim $q$ und das Epistom ist mit zwei grölseren, halb aufwärts gerichteten, leicht gekrümmten Dornen bewaffnet.

Drei Exemplare.

\section{Bledius fratellus n. $\mathrm{sp}$.}

Elongatus, parallelus, subconvexus, anterius opacus confertim subtiliter flavido-pubescens, elytris abdomineque nitidulis, niger, elytris posterius oblique flavis, antennis pedibusque rufulis, femoribus supra piceatis; thorace subquadrato dense subtilissime punctato medio linea tenui impresso, elytris hoc longioribus confertim subtiliter, abdomine indistincte punctatis. - Long. $1 \frac{1}{3}$ lin.

Dem $B l$. infans am nächsten stehend, ebenso gefärbt wie dieser, aber um das Doppelte gröfser, mit breiterem mattem Halsschild und längeren, dichter punktirten Flügeldecken. Der Körper ist gestreckt, gleichbreit, mäfsig gewölbt, Kopf und Halsschild matt, die Flügeldecken und der Hinterleib ziemlich glänzend, der Vorderkörper dicht und fein anliegend gelblich behaart, der Hinterleib nur mit sparsamen, etwas längeren Härchen, besonders am Hinterrande der einzelnen Segmente besetzt, - schwarz, die Flügeldecken an der Spitze mit einer breiten, an der Naht am Anfang des hintern Drittels beginnenden und beiderseits schräg aufwärts gegen den Seitenrand hinziehenden hellgelben Querbinde, die Fühler und Beine röthlich, die Schenkel auf der Oberseite pechfarben. Der Kopf ist so breit als das Halsschild, die Stirn wenig gewölbt mit einer feinen Querlinie zwischen den Ansatzstellen der Fühler. Diese sind etwa doppelt so lang als der Kopf, das 2te Glied mehr als doppelt so lang und etwa doppelt so breit als das 3 te, dieses mit den zwei folgenden von annähernd gleicher Länge, wenig länger 
als breit, die nächstfolgenden fünf Glieder stärker und allmählig etwas verbreitert, die vorletzten nicht ganz doppelt so breit als lang, das Endglied so lang fast als die zwei vorhergehenden zusammen, eiförmig mit abgerundeter Spitze. Der Mund mit den Tastern und Mandibeln ist hell rotbbraun, letztere in der Mitte mit einem langen, fast gleichbreiten, vorn stumpfen Zahn. Das Halsschild ist fast so breit als die Flügeldecken, quer quadratisch, vorn gerade abgeschnitten mit scharf rechtwinkeligen Vorderecken, an den Seiten bis zum hintern Drittel geradlinig, dann plötzlich unter stumpfem Winkel stark nach hinten verengt, am Hinterrand kaum halb so breit als vorn mit völlig verrundeten Hinterecken, oben gewölbt, in der Mitte von einer sehr feinen vorn und hinten abgekürzten Längslinie durchzogen, dicht und fein anliegend gelblich behaart, so dafs die äufserst feine dichte Punktirung nur schwer zu erkennen ist. Die Flügeldecken sind um ein Drittel länger als das Halsschild, dicht und fein punktirt und behaart, der Hinterleib an den Seiten sparsam und unbestimmt punktirt, an der äufsersten Spitze rothbraun. Die Beine sind gelblich, die obere Hälfte der Schenkel wenigstens bis in die Mitte pechfarbig.

In einiger Zahl gefunden.

\section{Trogophloeus globicollis n. sp.}

Niger, antennarum basi pedibusque testaceis, capite subtriangulari thorace angustiore thoraceque transversim suborbiculato dorso convexo aequali omnium creberrime subtilissimeque punctulatis, opacis; elytris thorace duplo fere longioribus nitidulis confertim distincte, abdomine nitido subtilissime punctatis. - Long. vix 1 lin.

Dem $T r$. despectus am nächsten stehend, aber fast doppelt so grofs und durch andere Kopfbildung und anders geformtes Halsschild ohne alle Eindrücke verschieden. Der Kopf ist fast dreieckig, etwas schmäler als das Halsschild, von den grofsen stark vorstehenden Augen an nach hinten viel stärker verengt als bei Tr. despectus, oben leicht gewölbt, äufserst dicht und fein punktirt und mit äufserst dichter und feiner hauchartiger Pubescenz bekleidet, matt. Die Fühler sind etwas kürzer als Kopf und Halsschild, schwarz, die zwei ersten Glieder bräunlich gelb, das 2te fast doppeit so lang und so dick als das 3te, das 4te um die Hälfte feiner und kürzer als das 3te, so lang als breit, das 5te entschieden länger als die beiden einschliefsenden und breiter als das 4 te, kaum aber stärker als das 6te, die beiden folgenden von gleicher Grölse, leicht transversal, die drei letzten entschieden stärker als die vorhergehenden, 
das Endglied eiförmig, zugespitzt. Das Halsschild ist um mehr als ein Drittel breiter als lang, vorn gerade abgeschnitten mit tief herabgeschlagenen abgerundeten Vorderecken, an den Seiten vorn stark gerundet erweitert, nach hinten entschieden verengt, im oberen Drittel am breitesten, am Hinterrande und den Hinterecken leicht gerundet, oben gewölbt, wie der Kopf punktirt und behaart, matt. Die Flügeldecken sind fast doppelt so breit als der Hinterrand des Halsschildes und fast um die Hälfte länger als dasselbe, auf dem Rücken ziemlich flach gedrückt, äufserst dicht, fein aber entschieden punktirt; ihre Behaarung ist etwas deutlicher und länger als die des Kopfes und Halsschildes, aber ebenfalls aufserordentlich fein. Der Hinterleib ist dicht und äufserst fein punktirt. Die Beine sind röthlichgelb.

In ungeheurer Anzahl gesammelt; ich glaube, dafs die Zahl gering gegriffen ist, wenn ich von 10,000 Stücken spreche. Das Thier scheint nach Art unserer kleinen Oxytelus-Arten in der Dämmerung haufenweise zu.schwärmen. Ueber den Fang desselben siehe Einleitung.

Trotz der habituellen Aehnlichkeit mit $T r$. despectus ist die neue Art doch ihrer Kopfbildung wegen nicht zur Untergattung Troginus zu stellen. In der Beschaffenheit der Fühler steht sie zwischen den ächten Trogophloeen und den Taenosomen gleichsam in der Mitte. Systematisch scheint mir dieselbe am richtigsten hinter Tr. politus gestellt.

\section{Trogophloeus Koppi n. sp.}

Elongatus, nitidulus, subtilissime tenuissimeque griseo-pubescens, piceus, capite nigro, antennarum basi, pedibus elytrisque testaceis; thorace transversim subcordato, basin versus angustato dorso 4 foveolato, elytris hoc dimidio longioribus confertim subtiliter punctatis. Long. $1-1 \frac{1}{5}$ lin.

Ganz von der Gestalt des Tr. corticinus und unreifen Stücken desselben täuschend ähnlich, etwas gröfser, durch längere stärkere Fühler und constant hellere Färbung abweichend. Der Körper ist gestreckt, etwas flach, überall äufserst zart und fein greis behaart, daher nur mattglänzend, äufserst dicht und fein punktirt, pechbraun oder röthlich-pechbraun mit schwarzem Kopfe und gelblichen Flügeldecken und Beinen. Der Kopf ist wenig schmäler als das Halsschild, die Stirn vorn neben dem Fühleransatze beiderseits mit einem länglichen Eindruck versehen. Der Mund und die Taster sind rothgelb. Die Fühler sind rothbraun, an der Basis und Spitze 
etwas heller, kräftig, wenig länger als Kopf und Halsschild, nach der Spitze allmählig stark verdickt, das 2te Glied etwas länger und dicker als das 3te, dieses kaum um die Hälfte länger als breit, das 4te leicht quer, die folgenden allmählig mehr und mehr verbreitert, die letzten drei daher keine deutlich abgesetzte Keule bildend, die vorletzten um mehr als die Hälfte breiter als lang, das Endglied kurz eiförmig, zugespitzt. Das Halsschild ist etwas schmäler als die Flügeldecken, an den Seiten vorn gerundet erweitert, nach hinten verengt, am Hinterrande mit den Hinterecken gerundet, vorn gerade abgeschnitten mit stumpf zugerundeten Vorderecken, oben wenig gewölbt, in der Mitte der Scheibe mit vier deutlich getrennten Grübchen, zwei oberen längeren und zwei unteren queren, zwischen denselben leicht erhaben. Die Flügeldecken sind nicht ganz um die Hälfte breiter als der Hinterrand des Halsschildes, fast um mehr als die Hälfte länger als dasselbe, auf dem Rücken flach, fein und äufserst dicht punktirt, vorn neben der Naht beiderseits kurz eingedrückt. Der Hinterleib ist äufserst fein und unbestimmt punktirt. Die Beine sind rothgelb.

Ebenfalls in grofser Anzahl, aber bei Weitem nicht so häufig als die vorige Art und ganz auf dieselbe Weise von Herrn Kopp gefangen, dem ich die Art dankbarlichst dedicire.

Ich würde dieselbe für eine unreife Form des $T r$. corticinus halten, wenn nicht hunderte von Stücken die gleiche Färbung hätten und die Fühler nicht constant länger und stärker wären mit queren vorletzten Gliedern und nicht deutlich abgesetzter Keule.

\section{Synopsis of the Philonthini of Boreal America by George H. Horn M. D.}

In dieser fleifsigen Arbeit werden neben Philonthus nur die Gattungen Cafus und Actobius angenommen; das Material ist wesentlich durch die Sammlungen unserer früheren Mitglieder Henry Ulke in Washington und E. A. Schwarz aus Liegnitz (jetzt im Agricultur-Departement) vermehrt. Von 85 Philonihus-Arten sind über 50 neue! Die 23 Actobius-Arten, zu denen der bekannte Philonthus cinerascens Grav. gehört, sind fast sämmtlich neu (21 unter 23), von den 10 Cafius -Arten nur 2. Deutschland hat etwa 70 Philonthus-Arten. Eine Anzahl von Arten hat Fauvel zur Ansicht gehabt und mit Namen belegt, die meist beibehalten sind.

Dr. G. Kraatz. 


\section{$2 \mathrm{BHL}$ Biodiversity Heritage Library}

Eppelsheim, Eduard. 1885. "Beitrag zur Staphylinenfauna West-Afrika's." Deutsche entomologische Zeitschrift 1885(1), 97-147. https://doi.org/10.1002/mmnd.48018850113.

View This Item Online: https://www.biodiversitylibrary.org/item/103411

DOI: https://doi.org/10.1002/mmnd.48018850113

Permalink: https://www.biodiversitylibrary.org/partpdf/235333

\section{Holding Institution}

Harvard University, Museum of Comparative Zoology, Ernst Mayr Library

\section{Sponsored by}

Harvard University, Museum of Comparative Zoology, Ernst Mayr Library

\section{Copyright \& Reuse}

Copyright Status: Public domain. The BHL considers that this work is no longer under copyright protection.

This document was created from content at the Biodiversity Heritage Library, the world's largest open access digital library for biodiversity literature and archives. Visit BHL at https://www.biodiversitylibrary.org. 